PNNL-11346

UC-510

\title{
Plutonium Dioxide Dissolution in Glass
}

John D. Vienna, David L. Alexander, Hong Li, and Michael J. Schweiger

Pacific Northwest National Laboratory, Richland, WA 99352

David K. Peeler and Thomas F. Meaker

Savannah River Technology Center, WSRC, Aiken, SC 29801

September 1996

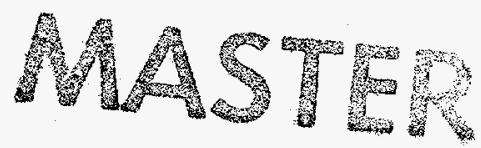

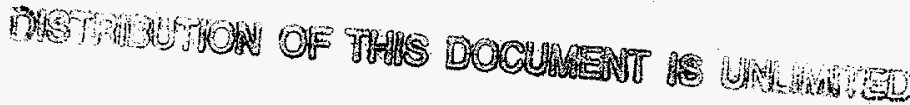

Prepared for the U.S. Department of Energy, under Contract DE-AC06-76RLO 1830

Pacific Northwest National Laboratory

Richland, Washington 99352 


\section{Disclaimer}

This report was prepared as an account of work sponsored by an agency of the United States Government. Neither the United States Government nor any agency thereof, nor Battelle Memorial Institute, nor any of their employees, makes any warranty, express or implied, or assumes any legal liability or responsibility for the accuracy, completeness, or usefulness of any information, apparatus, product, or process disclosed, or represents that its use would not infringe privately owned rights. Reference herein to any specific commercial product, process, or service by trade name, trademark, manufacturer, or otherwise does not necessarily constitute or imply its endorsement, recommendation, or favoring by the United States Government or any agency thereof, or Battelle Memorial Institute. The views and opinions of authors expressed herein do not necessarily state or reflect those of the United States Government or any agency thereof.

\section{PACIFIC NORTHWEST NATIONAL LABORATORY operated by BATTELLE MEMORIAL INSTITUTE for the UNITED STATES DEPARTMENT OF ENERGY under Contract DE-ACO6-76RLO 1830}

\section{Printed in the United States of America}

Available to DOE and DOE contractors from the Office of Scientific and Technical Information, P.O. Box 62, Oak Ridge, TN 37831; prices available from (615) 576-8401.

Available to the public from the National Technical Information Service, U.S. Department of Commerce, 5285 Port Royal Rd., Springfield, VA 22161

This document was printed on recycled paper. 


\section{DISCLAIMER}

Portions of this document may be illegible in electronic image products. Images are produced from the best available original document. 


\section{Executive Summary}

To prove the technical and economic feasibility of the dispositioning of excess weapons usable materials by vitrification, it is necessary to demonstrate that $\mathrm{PuO}_{2}$ feedstock can be dissolved in glass in sufficient quantity and in less than $8 \mathrm{~h}$. The objective of this study is to demonstrate a high $\mathrm{PuO}_{2}$ solubility in glass and to identify the rough time scale required for $\mathrm{PuO}_{2}$ dissolution in a candidate immobilization glass. The results of this study confirm that the $\mathrm{Pu}$ solubility can be as high as $10 \mathrm{wt} \%$ in glass $\left(11.4 \mathrm{wt} \% \mathrm{PuO}_{2}\right)$ and the time required for dissolution of $\mathrm{PuO}_{2}$ in glass was less than $4 \mathrm{~h}$ in every case and as low as 1 to $2 \mathrm{~h}$. This time requirement is based on a single glass composition and two $\mathrm{PuO}_{2}$ source materials with similar particle size distributions (PSD); one high-fired and one low-fired. Temperature, glass composition, and PSD of $\mathrm{PuO}_{2}$ are suspected being the major factors in $\mathrm{PuO}_{2}$ dissolution rates in glass. Additional tests are required to examine the effects of temperature, $\mathrm{PSD}$, and glass composition on $\mathrm{PuO}_{2}$ dissolution kinetics. 


\section{Contents}

Executive Summary $\ldots \ldots \ldots \ldots \ldots \ldots \ldots \ldots \ldots \ldots \ldots \ldots \ldots \ldots$ iii

Introduction $\ldots \ldots \ldots \ldots \ldots \ldots \ldots \ldots \ldots \ldots \ldots \ldots \ldots \ldots \ldots \ldots \ldots \ldots \ldots$

Experimental Approach $\ldots \ldots \ldots \ldots \ldots \ldots \ldots \ldots \ldots \ldots \ldots \ldots \ldots \ldots \ldots \ldots$

Low-Fired $\mathrm{PuO}_{2}$ Source $\ldots \ldots \ldots \ldots \ldots \ldots \ldots \ldots \ldots \ldots \ldots \ldots \ldots \ldots \ldots \ldots \ldots$

High-Fired $\mathrm{PuO}_{2}$ Source $\ldots \ldots \ldots \ldots \ldots \ldots \ldots \ldots \ldots \ldots \ldots \ldots \ldots \ldots \ldots$

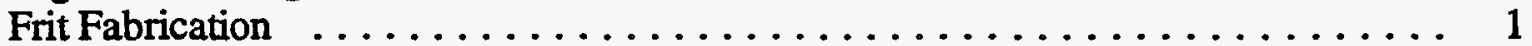

Spiking and Glass Fabrication $\ldots \ldots \ldots \ldots \ldots \ldots \ldots \ldots \ldots \ldots, 2$

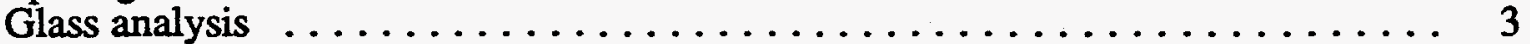

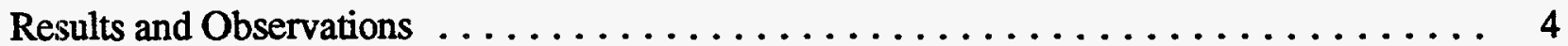

Frit and Feed $\ldots \ldots \ldots \ldots \ldots \ldots \ldots \ldots \ldots \ldots \ldots \ldots \ldots \ldots \ldots \ldots \ldots \ldots \ldots, 4$

Melt $1 \quad \ldots \ldots \ldots \ldots \ldots \ldots \ldots \ldots \ldots \ldots \ldots \ldots \ldots \ldots \ldots, 8$

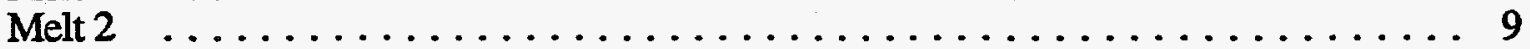

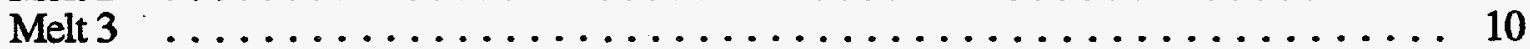

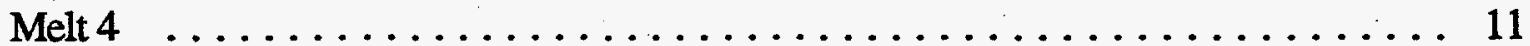

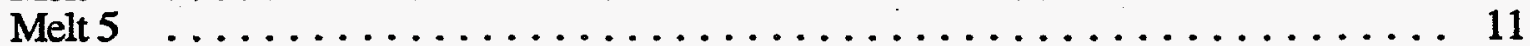

Melt $6 \quad \ldots \ldots \ldots \ldots \ldots \ldots \ldots \ldots \ldots \ldots \ldots \ldots \ldots \ldots \ldots \ldots \ldots \ldots \ldots \ldots \ldots \ldots \ldots \ldots \ldots, 12$

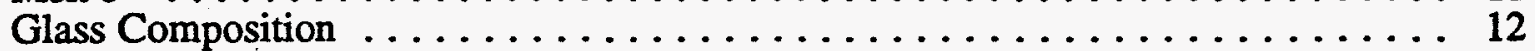

Summary and Discussion $\ldots \ldots \ldots \ldots \ldots \ldots \ldots \ldots \ldots \ldots \ldots \ldots \ldots \ldots \ldots$

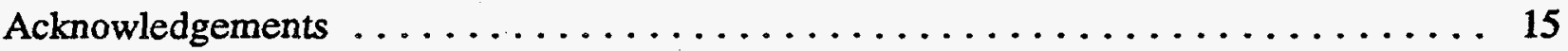

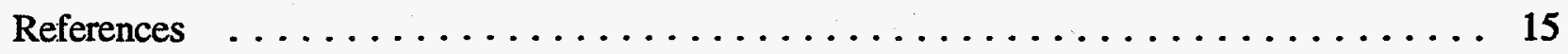

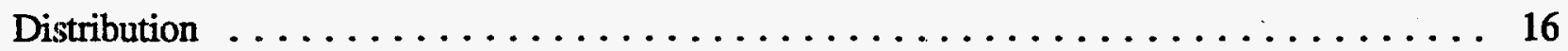

Appendix A - X-Ray Diffraction Results $\ldots \ldots \ldots \ldots \ldots \ldots \ldots \ldots \ldots \ldots \ldots \ldots \ldots \ldots$ A-1

Appendix B — Inductively Coupled Plasma / Mass Spectroscopy Results . . . . . . . . A-38

Appendix C - Radiochemical Analysis Results . . . . . . . . . . . . A 4 40 


\section{List of Figures}

Figure 1. Photomicrograph (SEM) of low-fired oxide crucible feed material $\ldots \ldots \ldots \ldots$

Figure 2. Photomicrograph $(\mathrm{SEM})$ of high-fired oxide crucible feed material $\ldots \ldots \ldots$

Figure 3. Unsuccessful attempt to stir hot glass $\ldots \ldots \ldots \ldots \ldots \ldots \ldots \ldots \ldots$

Figure 4. Melt 1 glass photograph $\ldots \ldots \ldots \ldots \ldots \ldots \ldots \ldots \ldots \ldots$

Figure 5. Successful stir of hot glass $\ldots \ldots \ldots \ldots \ldots \ldots \ldots \ldots \ldots \ldots$

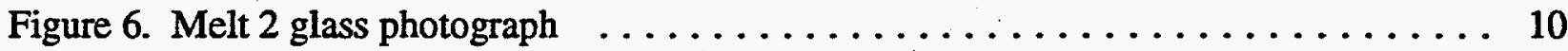

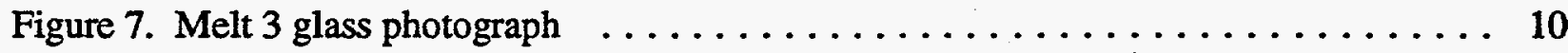

Figure 8. Melt 4 glass photograph $\ldots \ldots \ldots \ldots \ldots \ldots \ldots \ldots \ldots \ldots \ldots \ldots$

Figure 9. Melt 5 glass photograph $\ldots \ldots \ldots \ldots \ldots \ldots \ldots \ldots \ldots \ldots \ldots$

\section{List of Tables}

Table I. Frit and glass composition (as batched) $\ldots \ldots \ldots \ldots \ldots \ldots \ldots \ldots \ldots$

Table II. Melting history for $\operatorname{six}$ LaBS glasses $\ldots \ldots \ldots \ldots \ldots \ldots \ldots \ldots$

Table III. Glass sample identification. . . . . . . . . . . . . . . . . 4

Table IV. Viscosity temperature data for $\mathrm{LaBS}$ frit $\ldots \ldots \ldots \ldots \ldots \ldots$

Table V. Isotopics of $\mathrm{Pu}$ feed materials by radiochemical analysis $\ldots \ldots \ldots \ldots$

Table VI. Particle size distributions of $\mathrm{PuO}_{2}$ in crucible feed materials $\ldots \ldots \ldots \ldots$

Table VII. Mass spectroscopic analysis of glass composition $\ldots \ldots \ldots \ldots \ldots \ldots \ldots$

Table VIII. Alpha energy analysis of glass samples $\ldots \ldots \ldots \ldots \ldots \ldots$

Table IX. Mass percent isotopics of glass samples $\ldots \ldots \ldots \ldots \ldots \ldots \ldots$

Table X. Mass percent $\mathrm{Pu}$ and $\mathrm{PuO}_{2}$ in glass samples $\ldots \ldots \ldots \ldots \ldots$ 


\section{Introduction}

In the aftermath of the Cold War, the U.S. Department of Energy's (DOE) Office of Fissile Materials Disposition (OFMD) is charged with providing technical support for evaluation of disposition options for excess fissile materials manufactured for the nation's defense. One option being considered for the disposition of excess plutonium $(\mathrm{Pu})$ is immobilization by vitrification. The vitrification option entails immobilizing $\mathrm{Pu}$ in a host glass and waste package that are criticality-safe (immune to nuclear criticality), proliferation-resistant, and environmentally acceptable for long-term storage or disposal.

To prove the technical and economic feasibility of candidate vitrification options it is necessary to demonstrate that $\mathrm{PuO}_{2}$ feedstock can be dissolved in glass in sufficient quantity. The OFMD immobilization program has set a Pu solubility goal of $10 \mathrm{wt} \%$ in glass. The life cycle cost of the vitrification options are strongly influenced by the rate at which $\mathrm{PuO}_{2}$ dissolves in glass (DOE 1996). The total number of process lines needed for vitrification of $50 \mathrm{t}$ of $\mathrm{Pu}$ in 10 years is directly dependent upon the time required for Pu dissolution in glass.

The objective of this joint Pacific Northwest National Laboratory (PNNL) - Savannah River Technology Center (SRTC) study was to demonstrate a high Pu solubility in glass and to identify on a rough scale the time required for $\mathrm{Pu}$ dissolution in the glass. This study was conducted using a lanthanide borosilicate (LaBS) glass composition designed at the SRTC for the vitrification of actinides (Bibler et al. 1996).

\section{Experimental Approach}

\section{Low-Fired $\mathrm{PuO}_{2}$ Source}

The source $\mathrm{Pu}$ for low-fired oxide testing was obtained from a $20.2 \mathrm{~g} / \mathrm{L} 0.35 \mathrm{M}$ nitric acid solution (Pu blend 1). The solution was boiled in roughly $0.25 \mathrm{~L}$ batches in a teflon container at a temperature increasing from 200 to $270^{\circ} \mathrm{C}$ as the volume was reduced. Once a ten-fold reduction in volume was achieved, the liquid was transferred to an alumina crucible and heated in a muffle furnace between 270 and $300^{\circ} \mathrm{C}$, forming a thick foamy paste which was then completely dried. The dried $\mathrm{Pu}$ nitrate powder was calcined between 350 and $400^{\circ} \mathrm{C}$ for over 30 minutes for direct conversion to $\mathrm{PuO}_{2}$ according to the procedure in Wick (1980). Visual inspection of the calcined $\mathrm{PuO}_{2}$ showed a fine powder which was brownish green in color. Radiochemical analysis was performed to obtain material isotopics and mass fraction $\mathrm{Pu}$ (see Glass Composition Section).

\section{High-Fired $\mathrm{PuO}_{2}$ Source}

The source Pu for high-fired oxide testing was taken from a material lot of material with unknown history labeled "high-fired $\mathrm{PuO}_{2}$." An $89 \mathrm{~g}$ sample of the material was placed in a $\mathrm{MgO}$ crucible, fired at $1000^{\circ} \mathrm{C}$ for over $2 \mathrm{~h}$, and rapidly cooled to room temperature. Radiochemical analysis was performed (see Glass Composition Section) to obtain material isotopics and mass fraction $\mathrm{Pu}$ in the oxide material.

\section{Frit Fabrication}

The frit composition listed in Table I and used in this study is based on current work at 
SRTC regarding optimization of $\mathrm{Pu}$ solubility within the $\mathrm{LaBS}$ system. This frit (without $\mathrm{PuO}_{2}$ ) was fabricated according to standard test procedures (Hrma et al. 1994). A $500 \mathrm{~g}$ batch of frit was melted at $1450^{\circ} \mathrm{C}$ for $1 \mathrm{~h}$ in a covered $\mathrm{Pt} / \mathrm{Rh}$ crucible, steel quenched, and ground in a tungsten carbide mill for $3 \mathrm{~min}$. The viscosity-temperature curve for this frit was measured using a spindle type viscometer according to standard test procedures (Hrma et al. 1994) and augmented with two data points from a beam bending viscometer at low temperature.

Table I. LaBS frit and glass composition (as batched)

\begin{tabular}{||l|c|c|l||}
\hline Oxide & $\begin{array}{c}\text { wt\% in } \\
\text { Frit }\end{array}$ & $\begin{array}{c}\text { wt\% in } \\
\text { Glass }\end{array}$ & $\begin{array}{c}\text { Source } \\
\text { Chemical }\end{array}$ \\
\hline $\mathrm{SiO}_{2}$ & 29.13 & 25.80 & $\mathrm{SiO}_{2}$ \\
\hline $\mathrm{B}_{2} \mathrm{O}_{3}$ & 11.74 & 10.40 & $\mathrm{H}_{3} \mathrm{BO}_{3}$ \\
\hline $\mathrm{Al}_{2} \mathrm{O}_{3}$ & 21.49 & 19.04 & $\mathrm{Al}_{2} \mathrm{O}_{3}$ \\
\hline $\mathrm{ZrO}_{2}$ & 1.30 & 1.15 & $\mathrm{ZrO}_{2}$ \\
\hline $\mathrm{Gd}_{2} \mathrm{O}_{3}$ & 8.59 & 7.61 & $\mathrm{Gd}_{2} \mathrm{O}_{3}$ \\
\hline $\mathrm{La}_{2} \mathrm{O}_{3}$ & 12.43 & 11.01 & $\mathrm{La}_{2} \mathrm{O}_{3}$ \\
\hline $\mathrm{Nd}_{2} \mathrm{O}_{3}$ & 12.84 & 11.37 & $\mathrm{Nd}_{2} \mathrm{O}_{3}$ \\
\hline $\mathrm{PuO}_{2}$ & $\mathbf{0 . 0 0}$ & 11.39 & $\mathrm{PuO}_{2}$ \\
\hline $\mathrm{SrO}$ & 2.50 & 2.22 & $\mathrm{SrCO}_{3}$ \\
\hline \hline
\end{tabular}

\section{Spiking and Glass Fabrication}

Six glass melts were made to assess the effect of time, temperature, and stiring on the dissolution of $\mathrm{PuO}_{2}$ into the LaBS glass. The targeted glass composition is shown in Table $\mathrm{I}$. The targeted $11.39 \mathrm{wt} \% \mathrm{PuO}_{2}$ translates to $10.1 \mathrm{wt} \%$ of elemental $\mathrm{Pu}$ in the target glass composition. For each melt, $4.5 \mathrm{~g}$ of $\mathrm{PuO}_{2}$ was added to $35.5 \mathrm{~g}$ of frit to produce $40.0 \mathrm{~g}$ of glass. The frit/ $/ \mathrm{PuO}_{2}$ mixture was manually stirred, milled in an automated $\mathrm{Al}_{2} \mathrm{O}_{3}$ mortar and pestle for $1.75 \mathrm{~min}$, and loaded in a covered $\mathrm{Pt} / \mathrm{Rh}$ crucible for melting. The melt feeds (milled mixture of $\mathrm{PuO}_{2}$ and frit) were analyzed using scanning electron microscopy (SEM) to characterize particle size distribution (PSD) of frit and $\mathrm{PuO}_{2}$, mixedness, and morphology. Table $\mathrm{II}$ summarizes the melt history for the six melts. 
Table II. Melting history for six LaBS glasses

\begin{tabular}{||c|c|c|c|c|c||}
\hline Melt \# & Temperature & Time & Agitation & $\mathrm{PuO}_{2}$ Feed & Appearance \\
\hline 1 & $1450^{\circ} \mathrm{C}$ & $4 \mathrm{~h}$ & static & low-fired & layered \\
\hline 2 & 1500 & 4 & stirred $^{*}$ & low-fired & homogeneous \\
\hline 3 & 1500 & 2 & stirred $^{*}$ & low-fired & homogeneous \\
\hline 4 & 1500 & 4 & static & low-fired & homogeneous \\
\hline 5 & 1500 & 1 & stirred $^{*}$ & low-fired & layered \\
\hline 6 & 1500 & 4 & stirred $^{*}$ & high-fired & homogeneous \\
\hline
\end{tabular}

Melts were manually stirred twice during each melt using an Inconel rod for approximately 5 seconds.

\section{Glass analysis}

For each glass that visually appeared homogeneous, a representative sample containing bottom, top, and crucible side wall surfaces were obtained. For those samples that were actually composed of distinct layers (e.g., a layer of undissolved $\mathrm{PuO}_{2}$ on the bottom surface), representative samples from the top and bottom surfaces were taken and analyzed. Table III summarizes the analyses performed for each sample. For example, Melt \#1 $\left(1450^{\circ} \mathrm{C}, 4 \mathrm{~h}\right.$, static, low fired) visually had two distinct layers. A representative sample from the top (bulk) glass (sample V-4) and the undissolved layer (sample V-6) were taken for analysis. Sample V-4 was submitted for ICP/MS, XRD, and radiochemistry.

For $\mathrm{X}$-ray diffraction (XRD) analysis, the samples were milled and the powder was mixed with collodion and amyl acetate and then transferred to a glass slide. The amyl acetate was dried, leaving the glass sample "glued" to the slide with collodion. A fast XRD scan was performed on each sample from 10 to $80^{\circ}$ two-theta with a $3 \mathrm{~s}$ dwell and $0.05^{\circ}$ step size. A slow scan was performed on each sample from 25 to $35^{\circ}$ two-theta with a $20 \mathrm{~s}$ dwell and $0.02^{\circ}$ step size. The slow scan was performed over the $100 \%$ peak for $\mathrm{PuO}_{2}$ (JCPDS card \# 41-1170) to give increased sensitivity to undissolved $\mathrm{PuO}_{2}$. Calibration of the slow scan procedure has yielded an estimated $\mathrm{PuO}_{2}$ detection limit of $0.20 \mathrm{wt} \%$. 
Table III. Glass sample identification.

\begin{tabular}{|c|c|l|l|}
\hline Sample \# & Melt \# & Portion of Melt & Analyses Performed \\
\hline V-1 & 2 & top to bottom & ICP/MS, XRD, Radiochemistry \\
\hline V-2 & 4 & top to bottom & ICP/MS, XRD, Radiochemistry \\
\hline V-3 & 3 & top to bottom & ICP/MS, XRD, Radiochemistry \\
\hline V-4 & 1 & top & ICP/MS, XRD, Radiochemistry \\
\hline V-5 & 5 & top & ICP/MS, XRD, Radiochemistry \\
\hline V-6 & 1 & bottom & XRD \\
\hline V-7 & 5 & bottom & XRD \\
\hline V-8 & 6 & top to bottom & XRD, Radiochemistry \\
\hline
\end{tabular}

Glass composition was measured from the same representative samples that were fused in $\mathrm{KOH}$ in a Ni crucible. The solution was diluted to $1000 \mathrm{X}$ and analyzed using an inductively coupled plasma - mass spectrometer (ICP/MS). The relative error for these samples was determined to be $15 \%$ for all elements except $\mathrm{Al}$, which was subject to higher error. Equipment problems prohibited the measurement of $\mathrm{Si}$ in the sample. Radiochemistry was also performed on the starting nitrate and high-fired oxide feeds and on the fused glass samples with total alpha and ganma energy analysis and mass spectroscopy with a relative error of $6 \%$ or less for alpha analysis.

\section{Results and Observations}

\section{Frit and Feed}

The viscosity-temperature data of the frit is reported in Table IV. This data has been fitted to both Arrhenius (1) and Fulcher (2) viscosity equations:

$$
\ln (\eta)=A+\frac{B}{T},
$$

and

$$
\ln (\eta)=E+\frac{F}{T-T_{0}},
$$

where the constants $\mathrm{A}, \mathrm{B}, \mathrm{E}, \mathrm{F}$, and $\mathrm{T}_{0}$ are $-21.67,38152 \mathrm{~K},-9.88,10023 \mathrm{~K}$, and $764.0 \mathrm{~K}$, respectively. The Arrhenian activation energy for viscous flow is estimated at $1350^{\circ} \mathrm{C}$ to be 317 $\mathrm{KJ} / \mathrm{mol}$. The two melting temperatures 1450 and $1500^{\circ} \mathrm{C}$ correspond to viscosities of 2.05 and $1.33 \mathrm{~Pa} \cdot \mathrm{s}$, respectively (as predicted by the Fulcher equation). With an Arrhenius activation temperature of $38152 \mathrm{~K}$, the frit is considered to be extremely short compared to average high-level waste (HLW) glass with an activation temperature near $20000 \mathrm{~K}$. 
Table IV. Viscosity temperature data for LaBS frit

\begin{tabular}{||c|c|}
\hline $\mathrm{T}\left({ }^{\circ} \mathrm{C}\right)$ & $\eta(\mathrm{Pa} \cdot \mathrm{s})$ \\
\hline 1386 & 3.89 \\
\hline 1337 & 7.14 \\
\hline 1288 & 13.28 \\
\hline 1336 & 7.18 \\
\hline 1386 & 3.92 \\
\hline 1435 & 2.30 \\
\hline 1386 & 3.98 \\
\hline 1239 & 29.37 \\
\hline 1190 & 81.49 \\
\hline 1140 & 259.02 \\
\hline 782 & $6.5 \times 10^{10}$ \\
\hline 765 & $3.0 \times 10^{11}$ \\
\hline
\end{tabular}

The radiochemical analysis of the nitrate and high-fired oxide feedstocks are given in Table $\mathrm{V}$. The nitrate results show a solution concentration of $20.2 \mathrm{~g} / \mathrm{L}$ of actinides with $6.4 \mathrm{wt} \% 240 \mathrm{Pu}$. Upon calcination of the $1.0 \mathrm{~L}$ of feed material, $22.82 \mathrm{~g}$ of $\mathrm{PuO}_{2}$ were obtained which, when compared with the $22.88 \mathrm{~g}$ of $\mathrm{PuO}_{2}$ expected from radiochemical analysis, suggests little impurity in the $\mathrm{PuO}_{2}$ feed. 
Table V. Isotopics of Pu feed materials by radiochemical analysis

\begin{tabular}{||l|l|c|}
\hline & $\begin{array}{c}\text { Nitrate } \\
\text { Solution } \\
\left(\mathrm{g} / \mathrm{L}_{\text {Soln }}\right)\end{array}$ & $\begin{array}{c}\text { High-Fired } \\
\text { O/gide } \\
(\mathrm{g} / \text { goxide })\end{array}$ \\
\hline${ }^{238} \mathrm{Pu}$ & 0.0000 & 0.0006 \\
\hline${ }^{239} \mathrm{Pu}$ & 0.1884 & 0.7550 \\
\hline${ }^{240} \mathrm{Pu}$ & 0.0129 & 0.0829 \\
\hline${ }^{241} \mathrm{Pu}$ & 0.0004 & 0.0005 \\
\hline${ }^{241} \mathrm{Am}$ & 0.0000 & 0.0023 \\
\hline${ }^{242 \mathrm{Pu}}$ & 0.0001 & 0.0439 \\
\hline Total & 0.2018 & 0.8851 \\
\hline
\end{tabular}

The radiochemical analysis results of the high-fired oxide feed show a concentration of $88.51 \mathrm{~g}$ per $100 \mathrm{~g}$ of oxide with $8.3 \mathrm{wt} \% 240 \mathrm{Pu}$. Assuming the $\mathrm{Pu}$ is in the $\mathrm{Pu}^{4+}$ state in the oxide, oxygen will make up $11.8 \mathrm{~g}$ per $100 \mathrm{~g}$ of oxide, suggesting that the impurity level in this $\mathrm{PuO}_{2}$ feed is below detectable limits by this method.

Electron micrographs of the low-fired and high-fired oxide/frit mixtures are shown in Figures 1 and 2, respectively. The particle size distributions of the low- and high-fired oxides are listed in Table VI. For both feeds the particle size ranges from submicron to $5 \mu \mathrm{m}$. The high-fired oxide has slighly smaller particles with a weight average size of $2.7 \mu \mathrm{m}$ compared to $3.8 \mu \mathrm{m}$ for the low-fired oxide. The PSD is broader for the high-fired oxide with a $14.4 \%$ width at half max compared to $4.5 \%$ for the low-fired oxide. In both feeds, the frit material is was in the 10 to 50 $\mu \mathrm{m}$ range and well mixed with the smaller $\mathrm{PuO}_{2}$ paricles. 


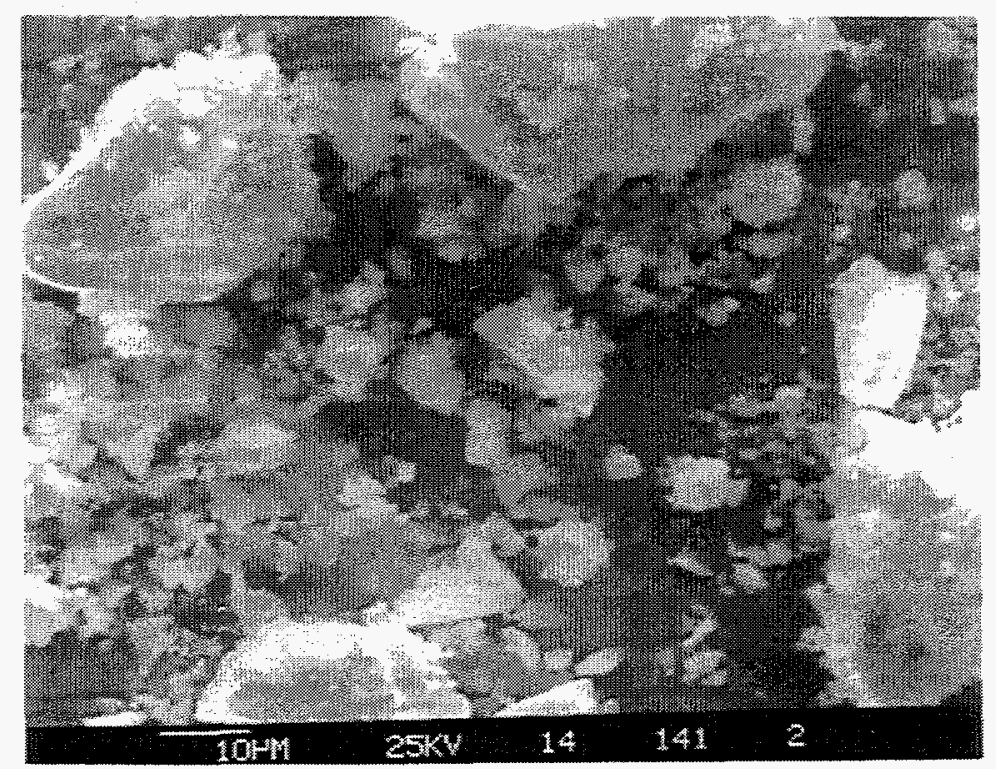

Figure 1. Photomicrograph (SEM) of low-fired oxide crucible feed material

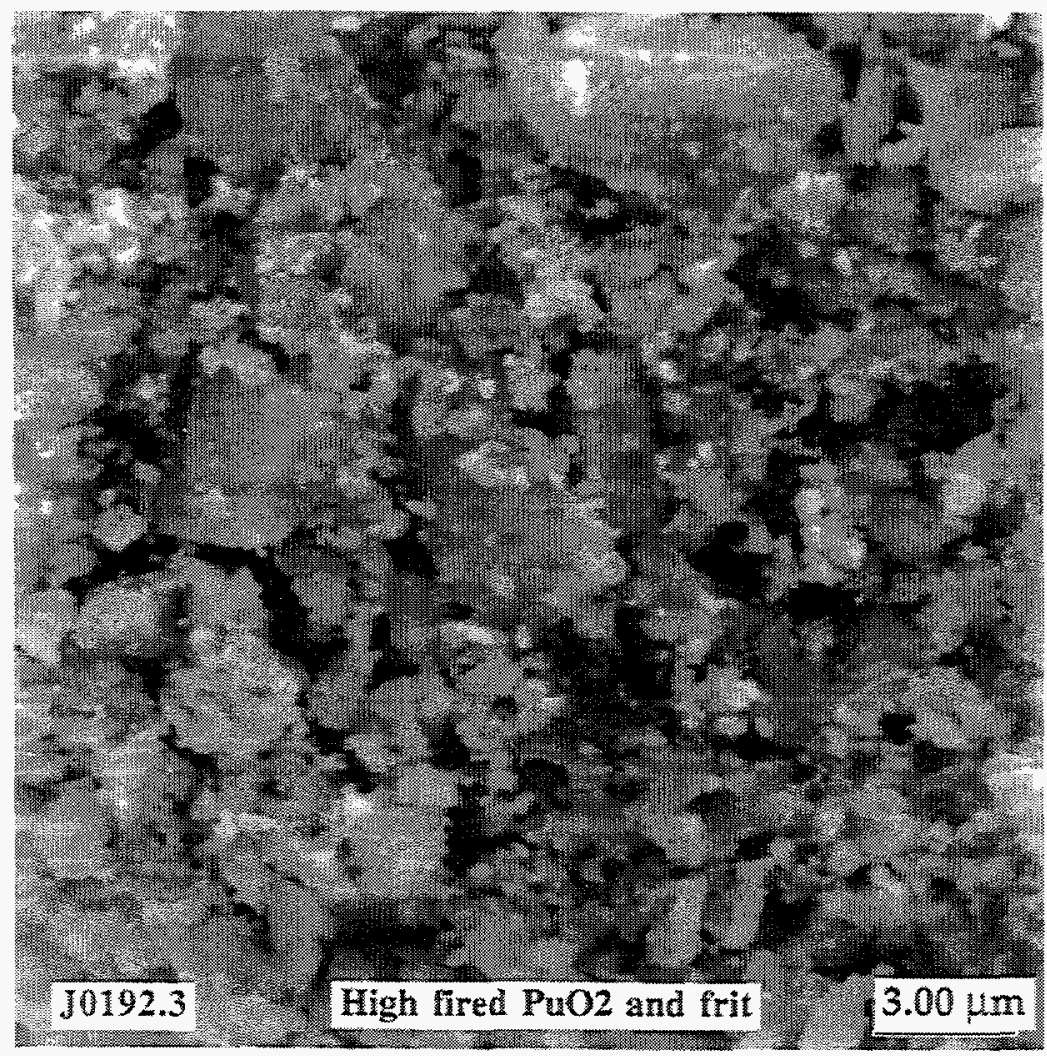

Figure 2. Photomicrograph (SEM) of high-fired oxide crucible feed material 
Table VI. Particle size distributions of $\mathrm{PuO}_{2}$ in crucible feed materials

\begin{tabular}{||l|c|c|c|c||}
\hline $\begin{array}{l}\text { Descrete } \\
\text { Sizes }\end{array}$ & $\begin{array}{c}\text { High-Fired } \\
\text { Oxide \% } \\
\text { Count }\end{array}$ & $\begin{array}{c}\text { Low-Fired } \\
\text { Oxide \% } \\
\text { Count }\end{array}$ & $\begin{array}{c}\text { High-Fired } \\
\text { Oxide } \\
\text { Mass \% }\end{array}$ & $\begin{array}{c}\text { Low-Fired } \\
\text { Oxide } \\
\text { Mass \% }\end{array}$ \\
\hline $0.0-0.5 \mu \mathrm{m}$ & 91.4 & 25.0 & 4.3 & 0.2 \\
\hline $0.5-1.0 \mu \mathrm{m}$ & 5.3 & 28.8 & 4.0 & 1.7 \\
\hline $1.0-1.5 \mu \mathrm{m}$ & 1.1 & 15.9 & 4.0 & 3.5 \\
\hline $1.5-2.0 \mu \mathrm{m}$ & 0.5 & 9.8 & 11.4 & 5.2 \\
\hline $2.0-3.0 \mu \mathrm{m}$ & 0.5 & 8.3 & 15.8 & 11.4 \\
\hline $3.0-5.0 \mu \mathrm{m}$ & 1.1 & 12.1 & 60.5 & 78.0 \\
\hline
\end{tabular}

\section{Melt 1}

The first melt was performed at $1450^{\circ} \mathrm{C}$ for $4 \mathrm{~h}$ under static conditions. After $1 \mathrm{~h}$ of melting, the glass was removed from the furnace for stirring. However, due to the low melting temperature, the high activation energy for viscous flow, and the relatively long period before stirring was attempted, the glass was far too viscous to stir (an estimated viscosity of $25-100$ $\mathrm{Pa} \cdot \mathrm{s}$ ). It was returned to the furnace and an attempt was made to stir at $2 \mathrm{~h}$. This attempt was again unsuccessful as shown in Figure 3.

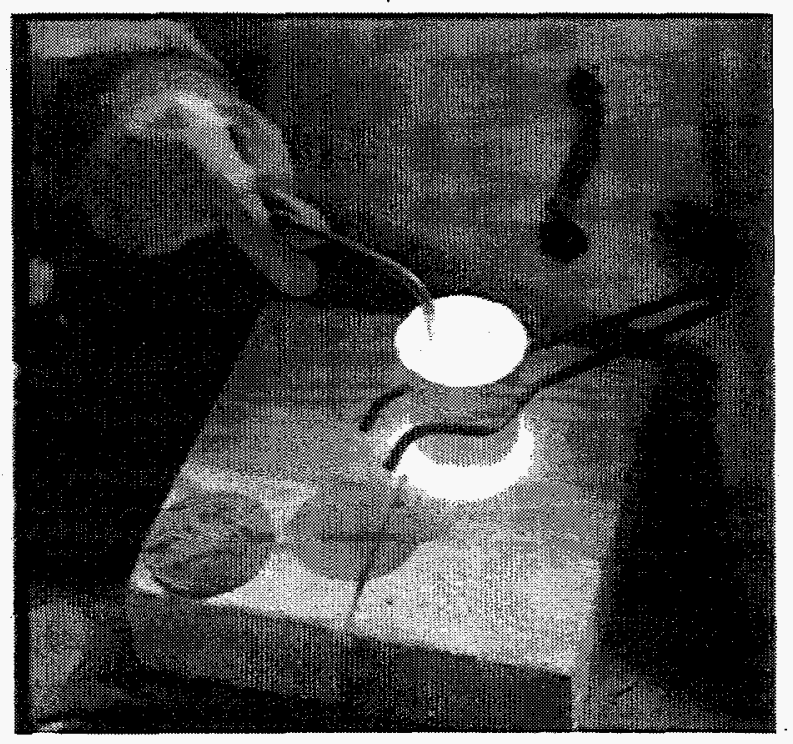

Figure 3. Unsuccessful attempt to stir hot glass

After $4 \mathrm{~h}$ of melting the glass was removed from the furnace and quenched by partially submerging the crucible in a water bath. The resulting glass was clear and dark green in color with 
a thin $(\sim 0.25 \mathrm{~mm})$ layer of brownish green crystals at the bottom of the melt. Figure 4 shows representative samples of the top and bottom layer. The XRD results for all samples are shown in Appendix A. According to XRD the top layer (sample V-4) is amorphous while the bottom layer (sample V-6) contains crystalline $\mathrm{PuO}_{2}$. Radiochemical and XRD analyses show that $8.32 \pm 0.50$ wt $\% \mathrm{Pu}$ (or $9.44 \pm 0.57 \mathrm{wt} \% \mathrm{PuO}_{2}$ ) was dissolved in the top amorphous layer of the glass.

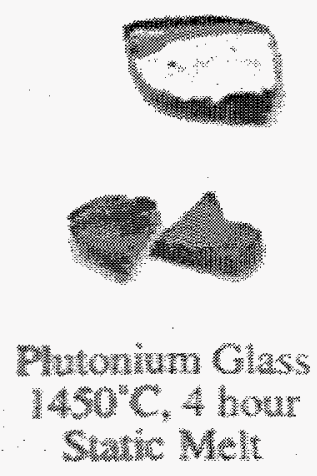

Figure 4. Melt 1 glass photograph

Melt 2

The second melt was performed at $1500^{\circ} \mathrm{C}$ for $4 \mathrm{~h}$. After $1 \mathrm{~h}$ of melting the glass was removed from the furnace for stirring. The glass viscosity was reasonably low with an estimated viscosity of $3-8 \mathrm{~Pa} \cdot \mathrm{s}$. The glass was stirred manually with an inconel stir rod for approximately $5-10 \mathrm{~s}$. It was returned to the furnace and stirred again at $2 \mathrm{~h}$. The successful stirring is shown in Figure 5.

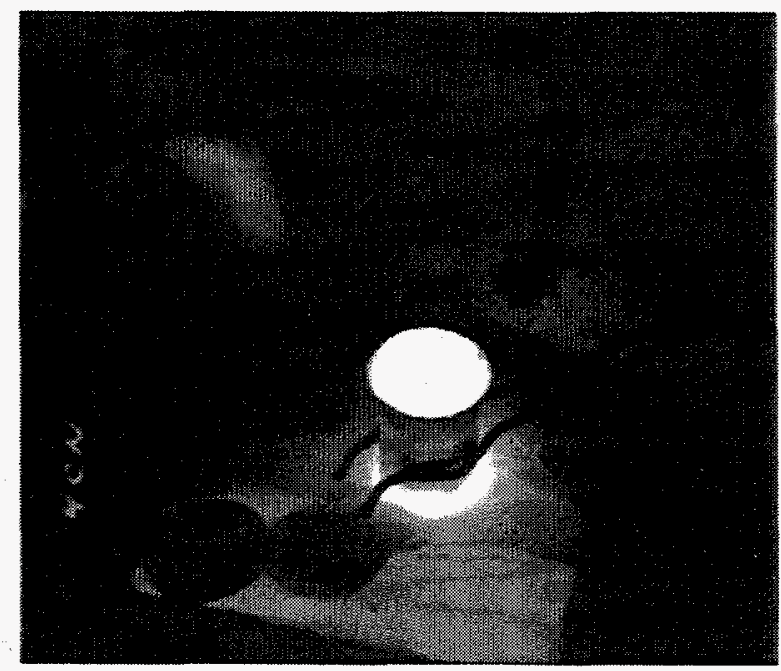

Figure 5. Successful stir of hot glass

After $4 \mathrm{~h}$ of melting the glass was transparent and dark green in color with no apparent 
layer at the bottom of the melt. Figure 6 shows representative samples of the glass viewed from the top (above) and the bottom (below). The XRD analysis of sample V-1 shows the sample is amorphous. Radiochemical and XRD analyses show that $10.11 \pm 0.61 \mathrm{wt} \% \mathrm{Pu}$ (or $11.47 \pm 0.69$ $\mathrm{wt} \% \mathrm{PuO}_{2}$ ) was completely dissolved in the glass.

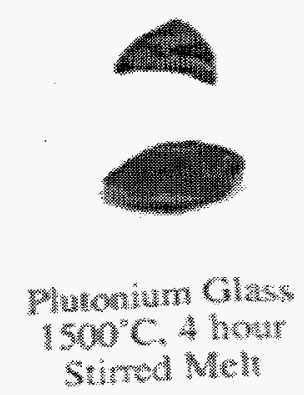

Figure 6. Melt 2 glass photograph

Melt 3

The third melt was performed at $1500^{\circ} \mathrm{C}$ for $2 \mathrm{~h}$. After $40 \mathrm{~min}$ of melting, the glass was removed from the furnace for stirring. The glass viscosity was reasonably low and the stir was successful (an estimated viscosity of $3-8 \mathrm{~Pa} \cdot \mathrm{s}$ ). It was returned to the furnace and stirred again at $80 \mathrm{~min}$.

After $2 \mathrm{~h}$ of melting, the glass was clear and dark green in color with no apparent layer at the bottom of the melt. Figure 7 shows reperesentative samples of the glass with the top view on top and the bottom view on bottom. The XRD analysis of sample V-3 shows the sample is amorphous. Radiochemical and XRD analyses show that $9.78 \pm 0.59 \mathrm{wt} \% \mathrm{Pu}$ (or $11.09 \pm 0.67$ wt $\% \mathrm{PuO}_{2}$ ) was completely dissolved in the glass. A concentration of $10 \mathrm{wt} \% \mathrm{Pu}$ is assumed, based on batching records and the large experimental errors associated with composition analyses.

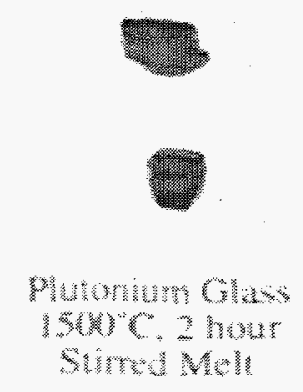

Figure 7. Melt 3 glass photograph 
Melt 4

The fourth melt was performed at $1500^{\circ} \mathrm{C}$ for $4 \mathrm{~h}$ under static conditions. After $4 \mathrm{~h}$ of melting, the glass was clear and dark green in color with no apparent layer at the bottom of the melt. Figure 8 shows representative samples of the glass with the top view on top and the bottom view on bottom. The XRD analysis of sample V-2 shows the sample is amorphous.

Radiochemical and XRD analyses show that $10.12 \pm 0.61 \mathrm{wt} \% \mathrm{Pu}$ (or $11.47 \pm 0.69 \mathrm{wt} \% \mathrm{PuO}_{2}$ ) was completely dissolved in the glass.

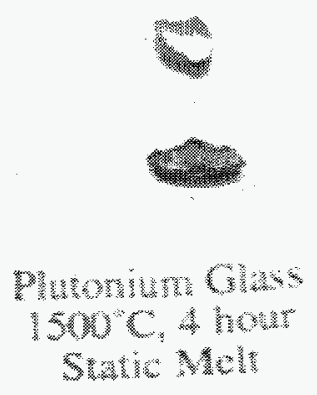

Figure 8. Melt 4 glass photograph

Melt 5

The fifth melt was performed at $1500^{\circ} \mathrm{C}$ for $1 \mathrm{~h}$. After 20 min of melting, the glass was removed from the furnace for stirring. The glass viscosity was reasonably low and the stir was successful (an estimated viscosity of $3-8 \mathrm{~Pa} \cdot \mathrm{s}$ ). It was returned to the furnace and stirred again at $40 \mathrm{~min}$.

After $1 \mathrm{~h}$ of melting, the glass was clear and dark green in color with a thin $(\sim 0.5 \mathrm{~mm})$ layer of brownish green crystals at the bottom of the melt. Figure 9 show representative samples of the glass with the top layer on top and the bottom layer on bottom. The XRD results show the top layer of glass (sample V-5) is amorphous while the bottom layer (sample V-7) contains crystalline $\mathrm{PuO}_{2}$. Radiochemical and XRD analyses show that $9.81 \pm 0.59$ wt\% $\mathrm{Pu}$ (or $11.13 \pm$ $0.67 \mathrm{wt} \% \mathrm{PuO}_{2}$ ) was dissolved in the top amorphous layer of the glass.

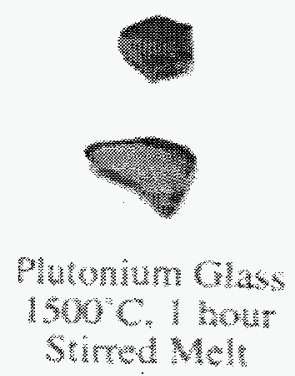

Figure 9. Melt 5 glass photograph 
Melt 6

The sixth melt was performed at $1500^{\circ} \mathrm{C}$ for $4 \mathrm{~h}$. After $1 \mathrm{~h}$ of melting the glass was removed from the furnace for stirring. The glass viscosity was reasonably low with an estimated viscosity of $3-8 \mathrm{~Pa} \cdot \mathrm{s}$. The glass was stirred manually with an inconel stir rod for approximately 5-10 s. It was returned to the furnace and stirred again at $2 \mathrm{~h}$. After $4 \mathrm{~h}$ of melting the glass was clear and dark green in color with no apparent layer at the bottom of the melt. The XRD analysis of sample V-8 shows the sample is amorphous. Radiochemical analyses were performed on four samples of this glass (V-8 a-d). The first two samples V-8a and b contained a portion of the melt top surface and no bottom surface. The final two samples $V-8 \mathrm{c}$ and $\mathrm{d}$ contained a portion of the melt bottom surface and no top surface. By taking samples in this mannor we attempted to gather $\mathrm{Pu}$ concentration information from different melt depths for analysis. These data show a concentration ranging from $5.2 \pm 0.1 \mathrm{wt} \% \mathrm{Pu}$ (or $5.9 \pm 0.1 \mathrm{wt} \% \mathrm{PuO}_{2}$ ) near the melt top to $11.8 \pm$ $0.2 w t \% \mathrm{Pu}$ (or $13.4 \pm 0.3 \mathrm{wt} \% \mathrm{PuO}_{2}$ ) near the crucible bottom.

\section{Glass Composition}

The analyzed sample compositions are listed in Table VII. These analyses are subjected to a relative error of $15 \%$ for all components except for Al. Analysis was not completed for Si due to equipment failure. Except for $\mathrm{Pu}$ and $\mathrm{Zr}$, all components in all samples match the batched composition within the experimental error. Low concentration readings for $\mathrm{Pu}$ and $\mathrm{Zr}$, which are highly refractory and traditionally have been difficult to analyze by ICP/MS of KOH fused samples, can likely be dismissed. Due to the high level of experimental error of glass composition analysis, no conclusions are drawn on these results. Radiochemical analysis of $\mathrm{Pu}$ in glass samples given in Tables VIII and IX confirm this conclusion. Table $\mathrm{X}$ shows $\mathrm{Pu}$ and $\mathrm{PuO}_{2}$ concentrations in glass based on radiochemical results.

Table VII. Mass spectroscopic analysis of glass composition in mass fraction

\begin{tabular}{||c|c|c|c|c|c|c||}
\hline & Target & $\mathrm{V}-1$ & $\mathrm{~V}-2$ & $\mathrm{~V}-3$ & $\mathrm{~V}-4$ & $\mathrm{~V}-5$ \\
\hline $\mathrm{SiO}_{2}$ & 0.258 & & & & & \\
\hline $\mathrm{B}_{2} \mathrm{O}_{3}$ & 0.104 & 0.090 & 0.104 & 0.094 & 0.100 & 0.105 \\
\hline $\mathrm{Al}_{2} \mathrm{O}_{3}$ & 0.190 & 0.223 & 0.221 & 0.202 & 0.225 & 0.217 \\
\hline $\mathrm{SrO}$ & 0.022 & 0.021 & 0.023 & 0.019 & 0.022 & 0.022 \\
\hline $\mathrm{ZrO}_{2}$ & 0.012 & 0.009 & 0.011 & 0.009 & 0.010 & 0.009 \\
\hline $\mathrm{La}_{2} \mathrm{O}_{3}$ & 0.110 & 0.097 & 0.114 & 0.092 & 0.100 & 0.103 \\
\hline $\mathrm{Nd}_{2} \mathrm{O}_{3}$ & 0.114 & 0.106 & 0.117 & 0.102 & 0.113 & 0.110 \\
\hline $\mathrm{Gd}_{2} \mathrm{O}_{3}$ & 0.076 & 0.067 & 0.078 & 0.064 & 0.068 & 0.073 \\
\hline $239 \mathrm{PuO}_{2}$ & 0.106 & 0.086 & 0.092 & 0.086 & 0.075 & 0.081 \\
\hline other $\mathrm{PuO}_{2}$ & 0.008 & & & & & \\
\hline Total & 1.000 & 0.700 & 0.760 & 0.668 & 0.713 & 0.721 \\
\hline
\end{tabular}


Table VIII. Alpha energy analysis of glass samples

\begin{tabular}{||c|c|c|}
\hline Sample & $\begin{array}{c}\text { Alpha } \\
(\mu \mathrm{Ci} / \mathrm{g})\end{array}$ & $\begin{array}{c}\text { Error } \\
(+/-)\end{array}$ \\
\hline $\mathrm{V}-1$ & 7,470 & $6 \%$ \\
\hline $\mathrm{V}-2$ & 7,450 & $6 \%$ \\
\hline $\mathrm{V}-3$ & 7,260 & $6 \%$ \\
\hline V-4 & 6,150 & $6 \%$ \\
\hline V-5 & 7,210 & $6 \%$ \\
\hline V-5 dup & 7,340 & $6 \%$ \\
\hline
\end{tabular}

Table IX. Mass percent isotopics of glass samples

\begin{tabular}{|c|c|c|c|c|c|}
\hline Mass & 238 & 239 & 240 & 241 & 242 \\
\hline V-1 & 0.013 & 93.340 & 6.411 & 0.194 & 0.042 \\
\hline V-2 & 0.011 & 93.349 & 6.415 & 0.189 & 0.036 \\
\hline V-3 & 0.015 & 93.362 & 6.387 & 0.197 & 0.039 \\
\hline V-4 & 0.013 & 93.383 & 6.375 & 0.193 & 0.036 \\
\hline V-5 & 0.014 & 93.338 & 6.415 & 0.190 & 0.042 \\
\hline V-8 & 0.010 & 96.012 & 2.859 & $0.137^{*}$ & 1.059 \\
\hline
\end{tabular}

Table X. Mass percent $\mathrm{Pu}$ and $\mathrm{PuO}_{2}$ in glass samples

\begin{tabular}{|c|c|c|c|}
\hline & $w t \% \mathrm{Pu}$ & wt\% $\mathrm{PuO}_{2}$ & Error \\
\hline $\mathrm{V}-1$ & 10.11 & 11.47 & $6 \%$ \\
\hline $\mathrm{V}-2$ & 10.12 & 11.47 & $6 \%$ \\
\hline $\mathrm{V}-3$ & 9.78 & 11.09 & $6 \%$ \\
\hline $\mathrm{V}-4$ & 8.32 & 9.44 & $6 \%$ \\
\hline $\mathrm{V}-5$ & 9.81 & 11.13 & $6 \%$ \\
\hline $\mathrm{V}-8 \mathrm{a}$ & 5.16 & 5.86 & $2 \%$ \\
\hline $\mathrm{V}-8 \mathrm{~b}$ & 7.77 & 8.82 & $2 \%$ \\
\hline $\mathrm{V}-8 \mathrm{c}$ & 11.78 & 13.36 & $2 \%$ \\
\hline $\mathrm{V}-8 \mathrm{~d}$ & 10.55 & 11.97 & $2 \%$ \\
\hline
\end{tabular}




\section{Summary and Discussion}

The results of this study confirm that the Pu solubility can be as high as $11.8 \mathrm{wt} \%$ in glass $\left(13.4 \mathrm{wt} \% \mathrm{PuO}_{2}\right)$. To date this is the highest reported solubility of $\mathrm{Pu}$ in any glass. This glass also contains a 1:1 molar ratio of lanthanide neutron absorbers (i.e., Gd) to Pu. High solubility was consistently shown in the six test glasses which ranged from 11.8 to $5.6 \mathrm{wt} \% \mathrm{Pu}$.

The time required for dissolution of the low-fired $\mathrm{PuO}_{2}$ in glass was between 1 and $2 \mathrm{~h}$ at $1500^{\circ} \mathrm{C}$ with stirring. Without stirring, the dissolution was complete in less than $4 \mathrm{~h}$ at $1500^{\circ} \mathrm{C}$ and wasn't complete in $4 \mathrm{~h}$ at $1450^{\circ} \mathrm{C}$. The time required for dissolution of the high-fired $\mathrm{PuO}_{2}$ in glass was less than $4 \mathrm{~h}$ at $1500^{\circ} \mathrm{C}$ with stirring. These time requirements are based on the glass composition tested and the particle size distributions of source of $\mathrm{PuO}_{2}$ as described above.

$\mathrm{PuO}_{2}$ settling rate plays a major role in determining the extent of dissolution. Once settled, dissolution of $\mathrm{PuO}_{2}$ in glass will be impaired. Particle settling rate is controlled by radius ( $\mathrm{r}$ ) to a greater extent than fluidity $(1 / \eta)$ as seen in Stokes settling equation (assuming spherical particles settling unhindered in a convection free viscous liquid):

$$
\frac{\mathrm{dx}}{\mathrm{dt}}=\frac{2}{9} \frac{\Delta \rho \mathrm{gr}^{2}}{\eta},
$$

where $\mathrm{x}$ is distance settled, $\mathrm{t}$ is time, $\Delta \rho$ is density difference, and $\mathrm{g}$ is acceleration due to gravity. According to Equation (3) the time required for a particle to settle, ts, a distance, $x$, is proportional to $\eta / r^{2} \Delta \rho$.

The time required for a particle to dissolve in glass, $t_{\mathrm{D}}$, is proportional to $\mathrm{r} \delta / \mathrm{D} \Delta \mathrm{c}$, where $\delta$ is the diffuse layer width, $D$ is the diffusion coefficient, and $\Delta c$ is the degree of undersaturation in the glass. Thus, for a particle to dissolve before it settles to the bottom of the crucible $t_{D} \leq t_{S}$, or:

$$
\frac{\mathrm{r} \delta}{\mathrm{KD} \Delta \mathrm{c}} \leq \frac{\mathrm{x} \eta}{\mathrm{kr}^{2} \Delta \rho \mathrm{g}}
$$

where $\mathrm{K}$ and $\mathrm{k}$ are constants. The diffusion coefficient is often taken to be inversely proportional to $\eta$ (Stokes-Einstein relationship), further simplifying the relationship between $t_{S}$ and $t_{D}$. Thus to first approximation, $t_{S} / t_{D} \propto r^{3}$, and independent of $\eta$.

The Pu dissolved in the high-fired oxide melt was not homogeneously distributed throughout the melt. The bottom of the melt was found to be richer in Pu than the top. This phenomenon is commonly observed in the melting of "lead crystal" glass melts where lead is richer at the crucible bottom. 


\section{Acknowledgements}

The authors would like to thank the individuals whose help in this study was invaluable for its eventual success. In particular, our gratitude goes to Pavel Hrma for many helpful discussions of the data, Evan Jenson for his expert analysis of glass crystallinity, Eric Wyse for mass spectroscopy of samples, Joel Tingey and Don Rinehart for their assistance in performing the study, Rick Steele for timely sample preparation and transfer, and Jarrod Crum for particle size distribution analysis.

\section{References}

DOE, (1996) Technical Summary Report for Surplus Weapons-Usable Plutonium Disposition, DOE/MD-0003, United States Department of Energy, Office of Fissile Materials Disposition, Washington DC.

P. R. Hrma, G. F. Piepel, M. J. Schweiger, D. E. Smith, D. S. Kim, P. E. Redgate, J. D. Vienna, C. A. LoPresti, D. B. Simpson, D. K. Peeler, and M. H. Langowski, (1994) Property / Composition Relationships for Hanford High-Level Waste Glasses Melting at $1150^{\circ} \mathrm{C}$, Vol. 1, PNL-10359, Pacific Northwest National Laboratory, Richland, WA.

N. E. Bibler, W. G. Ramsey, T. F. Meaker, and J. M. Pareizs, (1996) "Durabilities of Radioactive Glasses for Immobilization of Excess Actinides at the Savannah River Site," Mat. Res. Symp. Proc., Vol. 412, Scientific Basis for Nuclear Waste Management XIX, Materials Research Society, Pittsburgh, PA, pp. 65-72.

O. J. Wick, (1980) Plutonium Handbook, The American Nuclear Society, LaGrange Park, IL. 


\section{Distribution}

no. of

copies

2 DOE/Office Of Scientific and Technical Information

2 DOE/Office of Fissile Materials Disposition Forrestal Building 1000 Independence Ave., S.W. Washington, DC 20585
A. K. Caponiti
W. J. Danker

4 DOE/Richland Operations Office Richland, WA 99352
A. B. Joy
J. E. Mecca
R. S. Ollero
C. R. Richins

3 Argonne National Laboratory

9700 S. Cass Ave.

Argonne, IL 60439
J. K. Bates
D. B. Chamberlain
D. M. Strachan

20 Savannah River Technology Center Westinghouse Savannah River Company Aiken, SC 29801
N. E. Bibler
D. A. Crowley
E. F. Duhn
E. W. Holtzscheiter
J. C. Marra
T. F. Meaker
L. M. Papouchado
J. M. Pareizs
D. K. Peeler (10)
M. J. Plodinec
I. K. Sullivan

no. of

copies

6 Lawrence Livermore National Laboratory

University of California

7000 East Ave.

Livermore, CA 94551

G. A. Armantrout

W. L. Bourcier

L. W. Gray

T. Kan

J. N. Kass

H. F. Shaw

6 Westinghouse Hanford Company

PO Box 1970

Richland, WA 99352

T. W. Crawford

R. C. Hoyt

D. C. Lini

R. W. Szempruch

T. J. Venetz

R. A. Watrous

29 Pacific Northwest National Laboratory PO Box 999, Battelle Blvd.

Richland, WA 99352

Document Management Files (5)

D. L. Alexander

J. L. Buelt

M. L. Elliott

D. L. Haggard

P. R. Hrma

E. D. Jenson

H. Li

J. M. Perez

M. E. Peterson

M. J. Schweiger

L. J. Sealock

R. T. Steele

J. M. Tingey

J. D. Vienna (10)

W. J. Weber 


\section{Appendix A}

\section{X-Ray Diffraction Results}

The following figures show the XRD scans from glass samples listed in Table III. The glasses were prepared and analyzed according to the procedures listed above. 
Date September 16, 1996

To J. D. Vienna

From E. D. Jenson

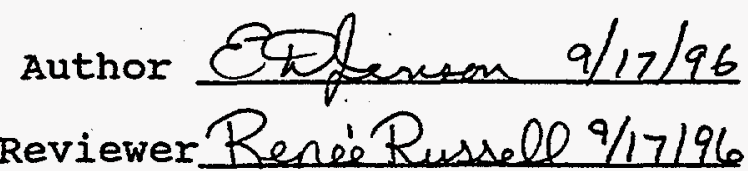

Subject XRD Examination of Glasses Containing $\mathrm{PuO}_{2}$, ReV 1

\section{Surnmary}

Eight samples of glass containing $\mathrm{PuO}_{2}$ were examined using $\mathrm{X}$-ray diffraction to determine which samples had crystalline $\mathrm{PuO}_{2}$ present. only glasses $\mathrm{V} 6$ and $V 7$ contained a detectable amount of crystalline $\mathrm{PuO}_{2}$.

Sample Identification

Sample $\quad$ Description

$\begin{array}{lll}\text { V1 } & 1500 \mathrm{deg}, 4 \mathrm{hr}, \text { stirred } & 960711 \mathrm{~A}, \mathrm{~B} \\ \text { V2 } & 1500 \mathrm{deg}, 4 \mathrm{hr}, \text { static } & 960718 \mathrm{~A} \text { and } \\ \text { V3 } & 1500 \mathrm{deg}, 2 \mathrm{hr}, \text { stirred } & 960806 \mathrm{~A} \\ \text { V4 } & 1450 \mathrm{deg}, 4 \mathrm{hr}, \text { static, top layer } & 960722 \mathrm{~A}, \mathrm{~B} \\ \text { V5 } & 1500 \mathrm{deg}, 1 \mathrm{hr}, \text { stirred, top layer } & 960802 \mathrm{~A}, \mathrm{~B} \\ \text { V6 } & 1450 \mathrm{deg}, 4 \mathrm{hr}, \text { static, bottom layer } & 960730 \mathrm{~A}, \mathrm{~B} \\ \text { V7 } & 1500 \mathrm{deg}, 1 \mathrm{hr}, \text { stirred, bottom layer } & 960801 \mathrm{~A}, \mathrm{~B} \\ \text { V8 } & 1550 \mathrm{deg}, 4 \mathrm{hr}, \text { stirred, high fired } & 960911 \mathrm{~A}, \mathrm{~B}\end{array}$

File Name

Data

Raw data plots over the full range covered (short count time) for the above samples are shown in Figures 1 through 7 and 30 . Figures 8 through 14 and 31 show the raw data plots for the 25 to 35 degree range (long count time). Background subtracted data are shown in Figures 15 through 21 and 32 (short count, full range) and 22 through 28 and 33 (long count, short range). "stick figure" displays of the $\mathrm{PuO}_{2}$ pattern, ICDD card 41-1170, are shown beneath the background subtracted data. Figure 34 shows an expanded view of the 53 degree range of sample V8.

A sample containing $3 \% \mathrm{PuO}_{2}$, with no heat treatment, was prepared to get an estimate of the detectability limit. This sample gave a peak height (of the 28 degree line) of $3479 \pm 116$ (standard deviation is 2 sigma) above background. Based on a background of $4753 \pm 110$, a concentration of $0.2 \% \mathrm{PuO}_{2}$ should be the minimum detectable concentration under these conditions. The calculation is as follows:

$$
\%=2 * \operatorname{sqr}\left((58) \wedge 2+\left(55^{\wedge} 2\right)\right) * 3 \% / 3479=0.2 \%
$$

This figure applies to a sample of the same area exposed to the $x-$ ray beam and the same thickness, since a major portion of the beam 
is expected to pass through the sample. Figure 29 shows the plot from the $3 \% \mathrm{PuO}_{2}$ in glass sample.

The degree of crystallinity of samples $V 6$ and $V 7$ could not be determined since the blank data (from microscope slide + collodion) showed higher counting rates than the sample.

Sample V8, Figure 32 , shows some apparent peaks at $40.6,53.1,61.6$ and 65.9 degrees 2-theta. These are difficult to see in the raw data. The 40.6 and 65.9 degree apparent peaks are less than the 2sigma noise value of the adjacent data, therefore these apparent peaks can be rejected as not real. The 53.1 and 61.6 degree apparent peaks exceed the 2-sigma noise level, but not the 3-sigma level in the raw data, therefore raising the question as to their reality. Detailed examination of the raw data shows the apparent peaks are really a series of adjacent points with intensities within the 2-sigma range but each having nearly the same value near the high end of the 2-sigma range. In the smoothing process, nearby data was smoothed to a value near the average, but the apparent peak points smoothed to a little higher value giving the appearance of a peak. An expanded view of the 53.1 degree range raw data is given in Figure 33, showing the lack of a real peak in this range.

\section{Experimental}

Samples V1, V2, V5, V6, V7 and V8 were prepared in the Process Chemistry fume hood adjacent to the glove box in which the glasses were fabricated. Samples V3 and V4 were prepared in the ACL hot cells in the 325 building. In each case 10 to $20 \mathrm{mg}$ of the sample was placed in a glass container (or boron carbide mortar), a few drops of $5 \%$ collodion in amyl acetate were added and mixed to form a smooth slurry, then the slurry was transferred to a glass slide and the solvent allowed to evaporate.

The sample was examined using the Scintag PAD V XRD in room 409 of the 325 building, property number WB81320. Running conditions for the short count, full range run were 0.05 degree 2 -theta step size at 1 degree/minute speed with a range of 5 to 75 degrees, except sample V1 which had 20 to 60 and sample V2 which had 5 to 70 degrees. The long count time, short range runs had parameters of 0.02 degrees 2 -theta step size, 20 seconds per step counting time with a range of 25 to 35 degrees 2-theta. X-ray parameters were 45 $\mathrm{Kv}$ and $40 \mathrm{ma}$ with a copper anode. Slits were $4,2,0.5$ and $0.3 \mathrm{~mm}$. The XRD was within calibration at all times as shown by the daily calibration check.

The work was performed to technical procedure PNL-ALO-268, Solids Analysis, X-ray Diffraction. Calibration data are in PNL LRB 53224. Daily calibration check data are in the operators notebook. 


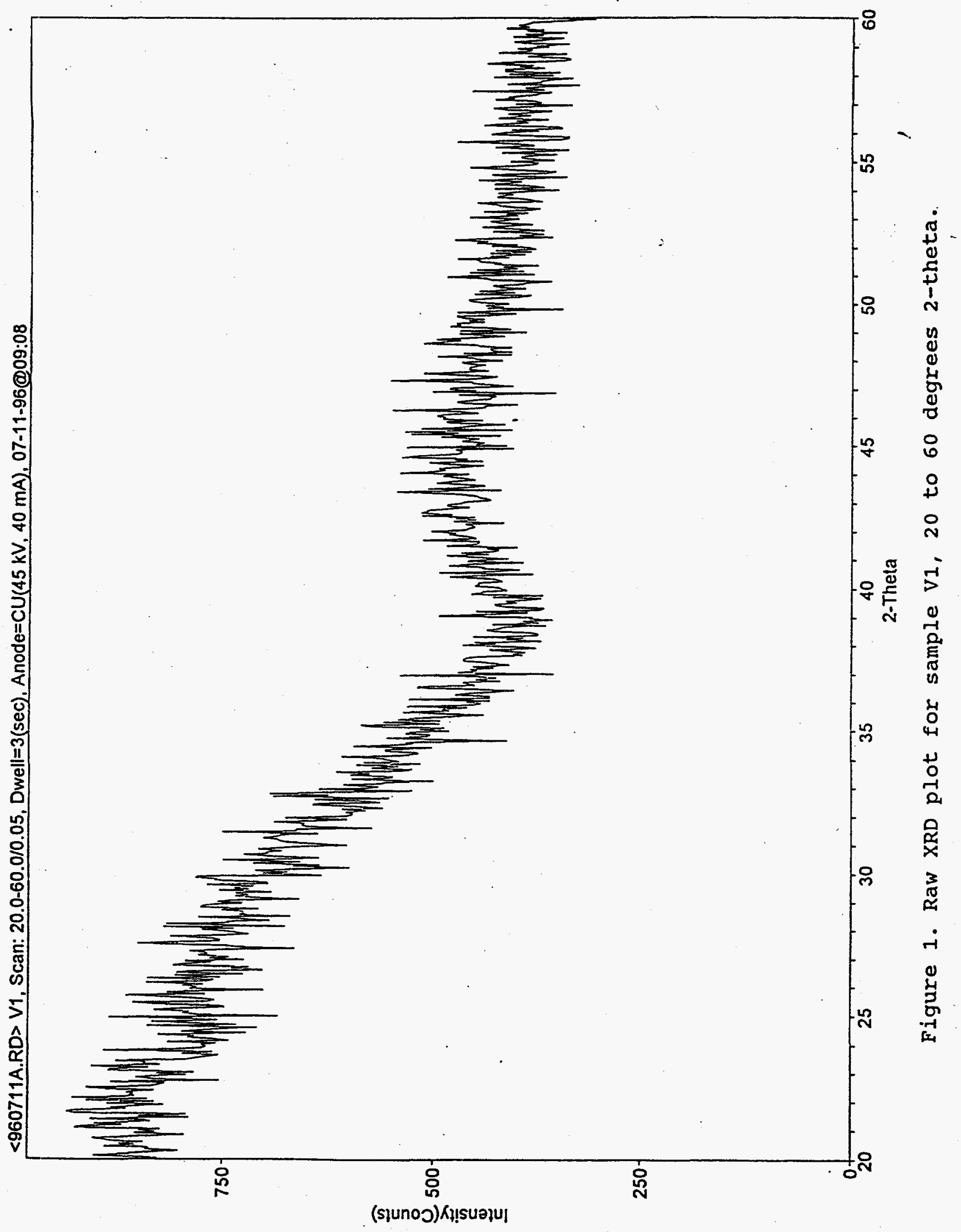




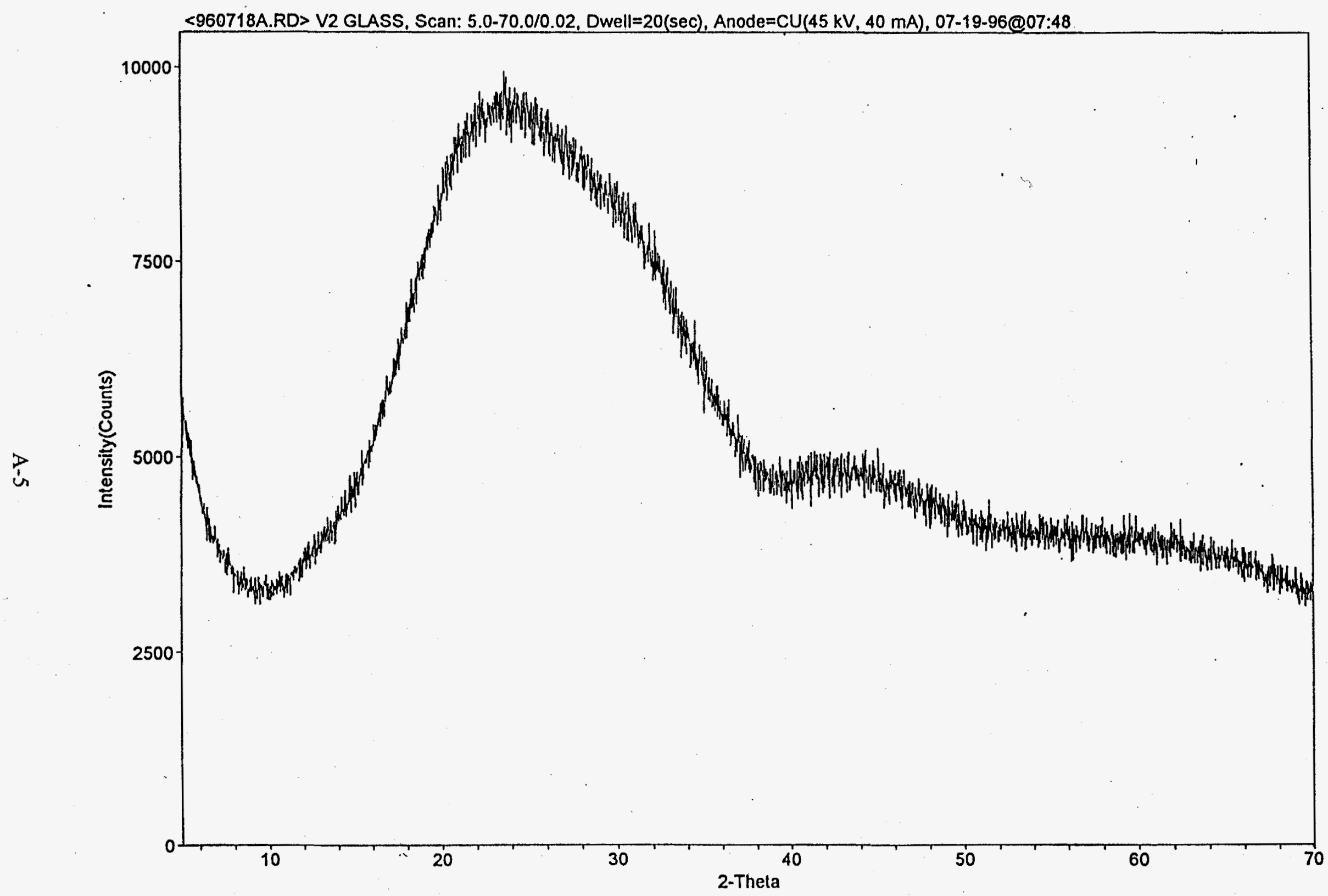

Figure 2. Raw XRD plot for sample V2, 5 to 70 degrees 2-theta. 


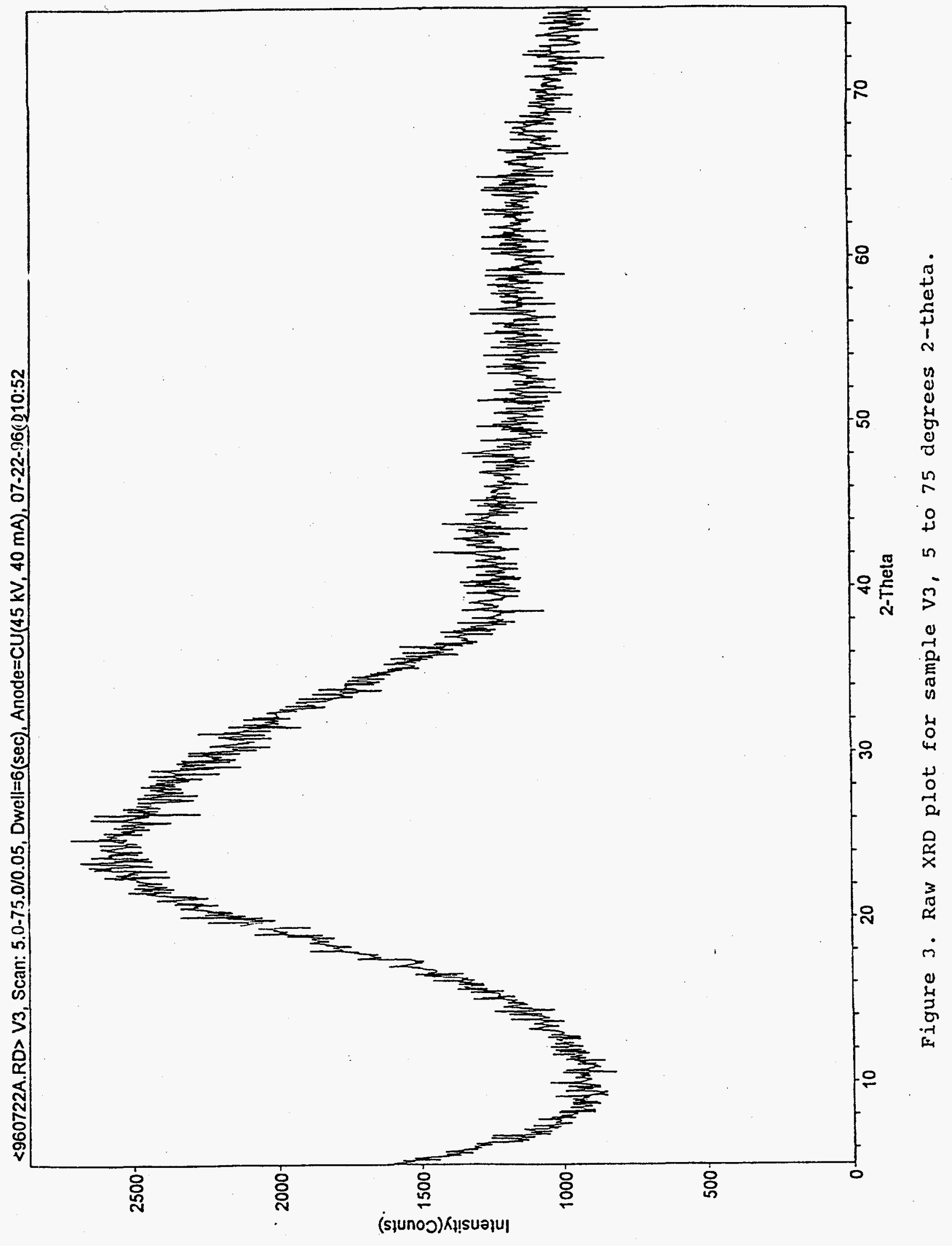




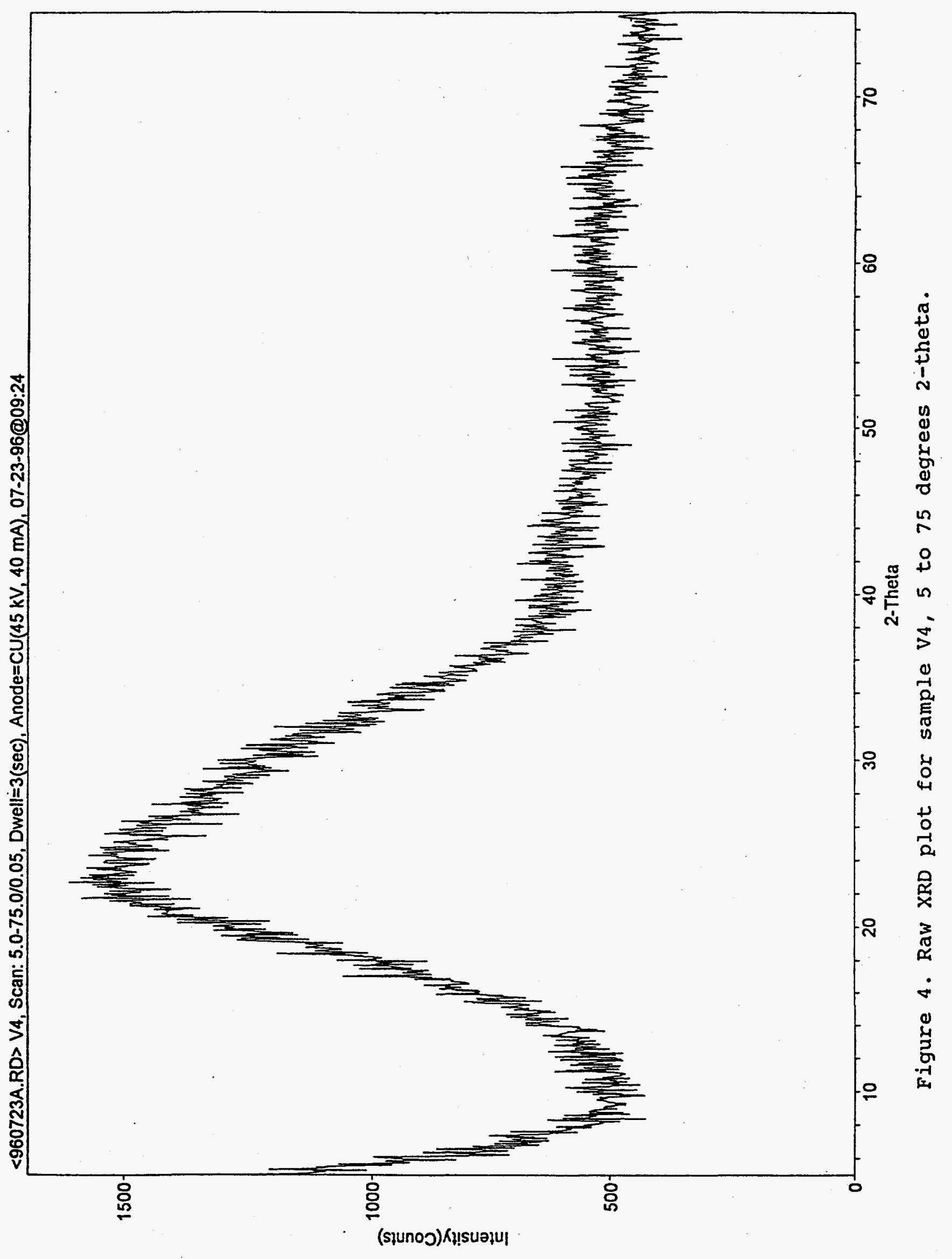

A-7 


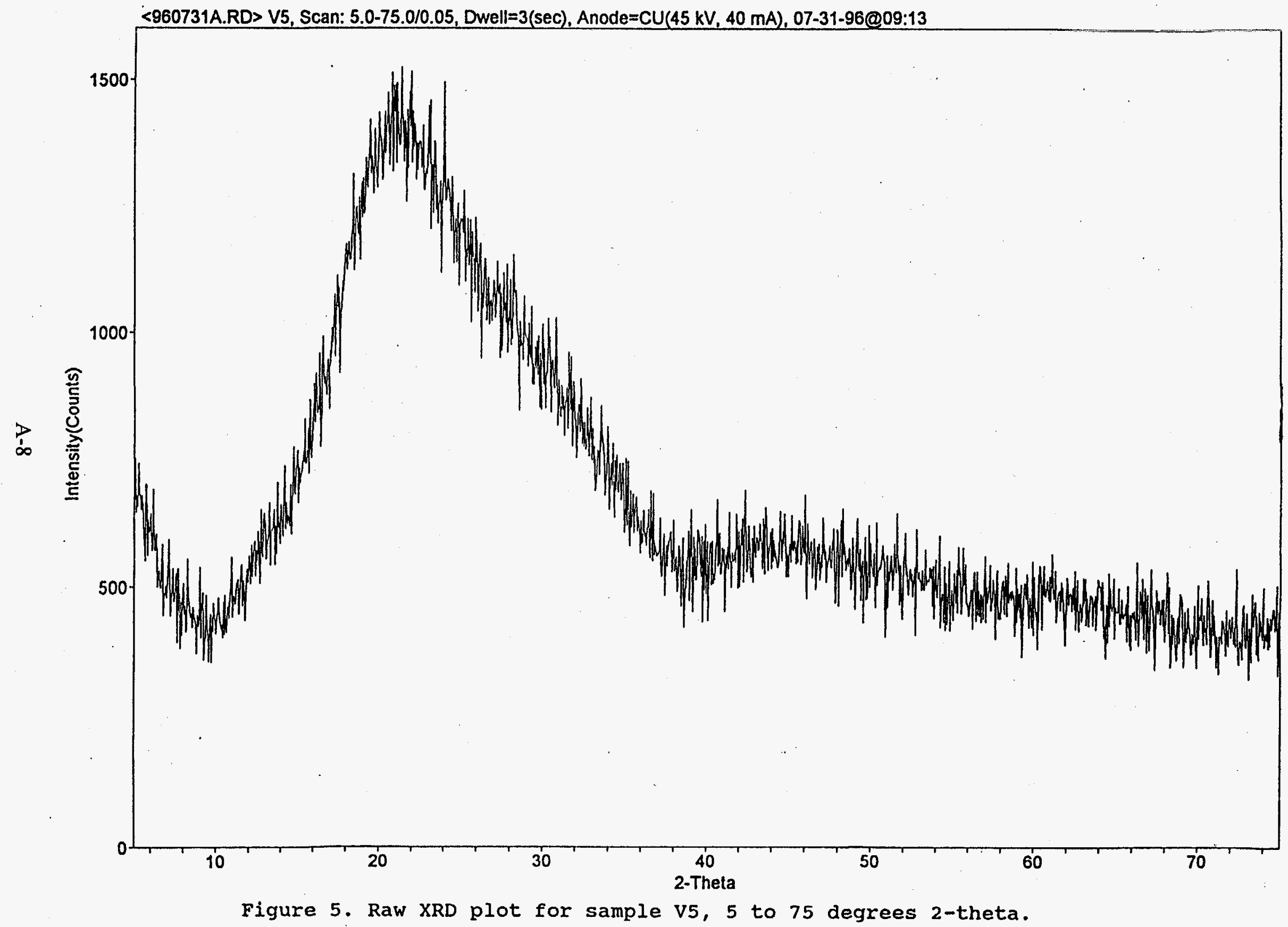




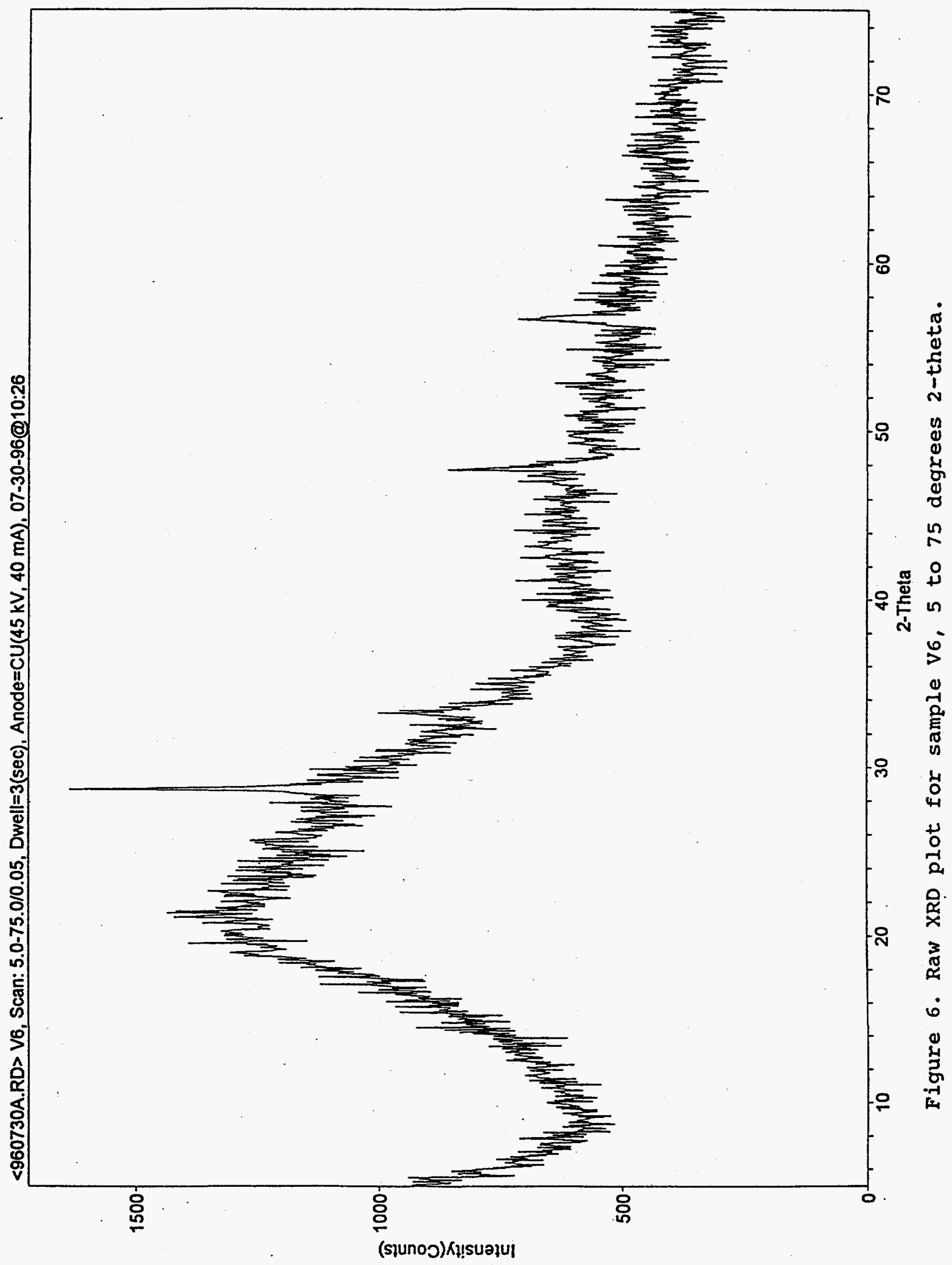

A-9 


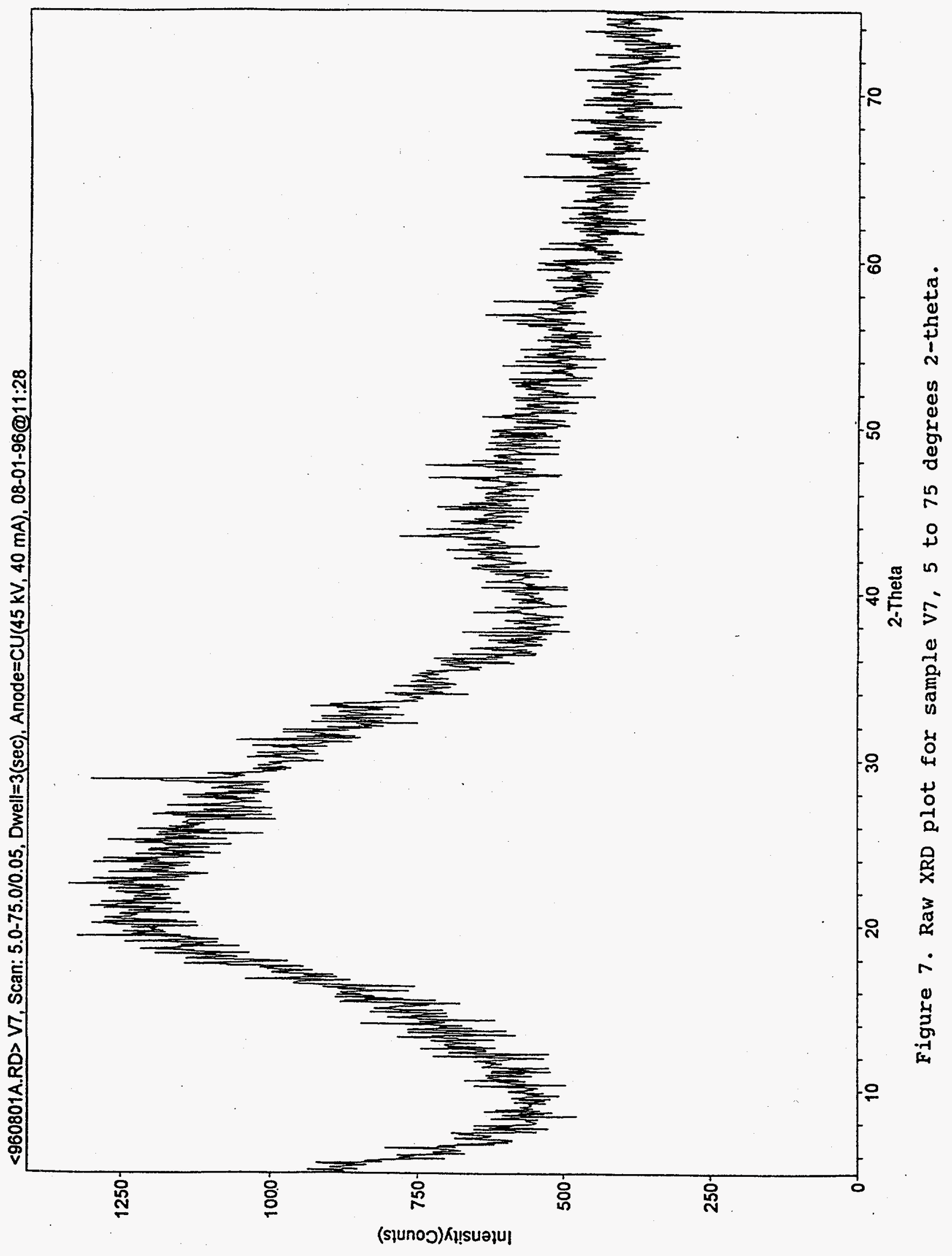

A-10 


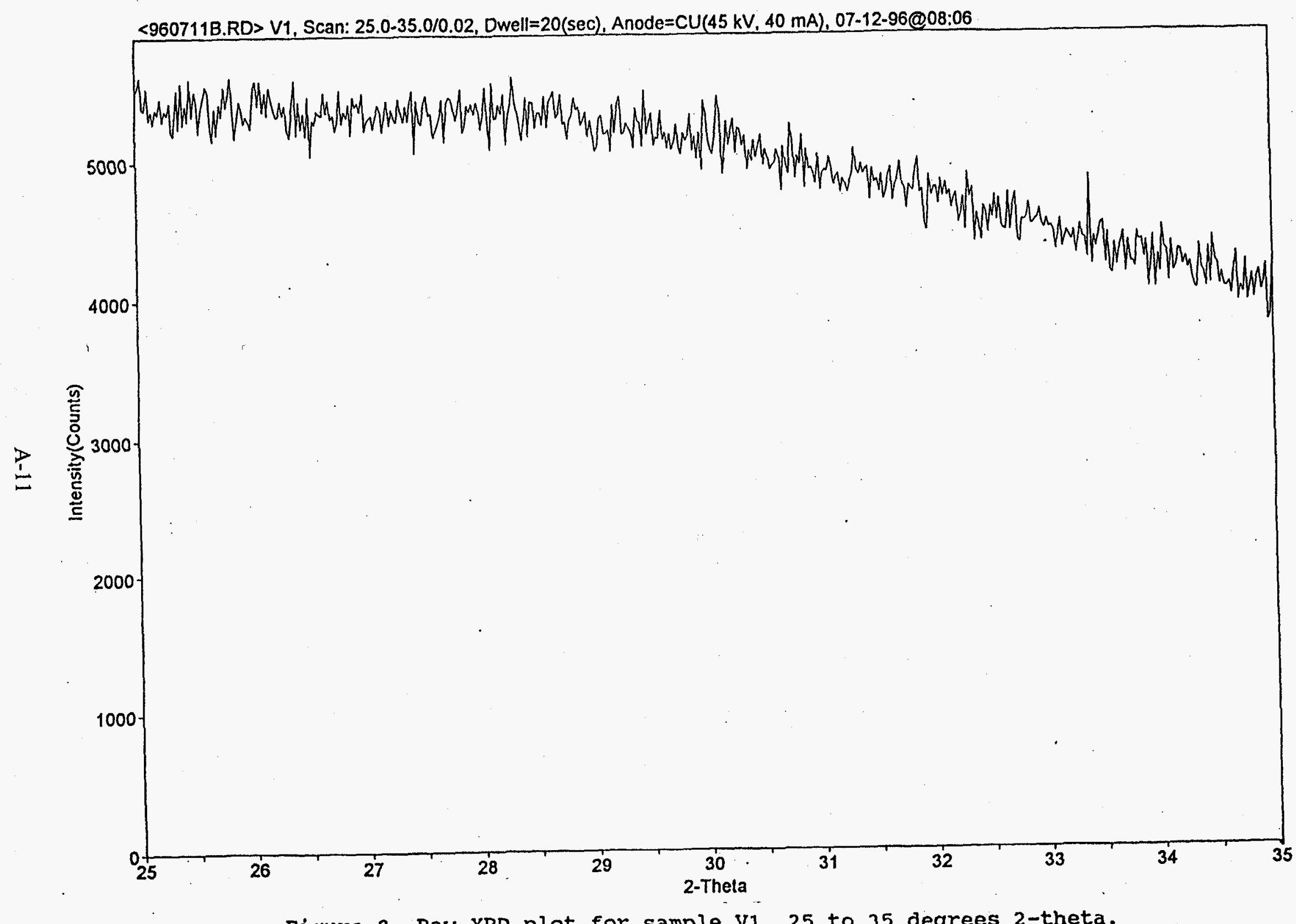

Figure 8. Raw XRD plot for sample V1, 25 to 35 degrees 2-theta. 


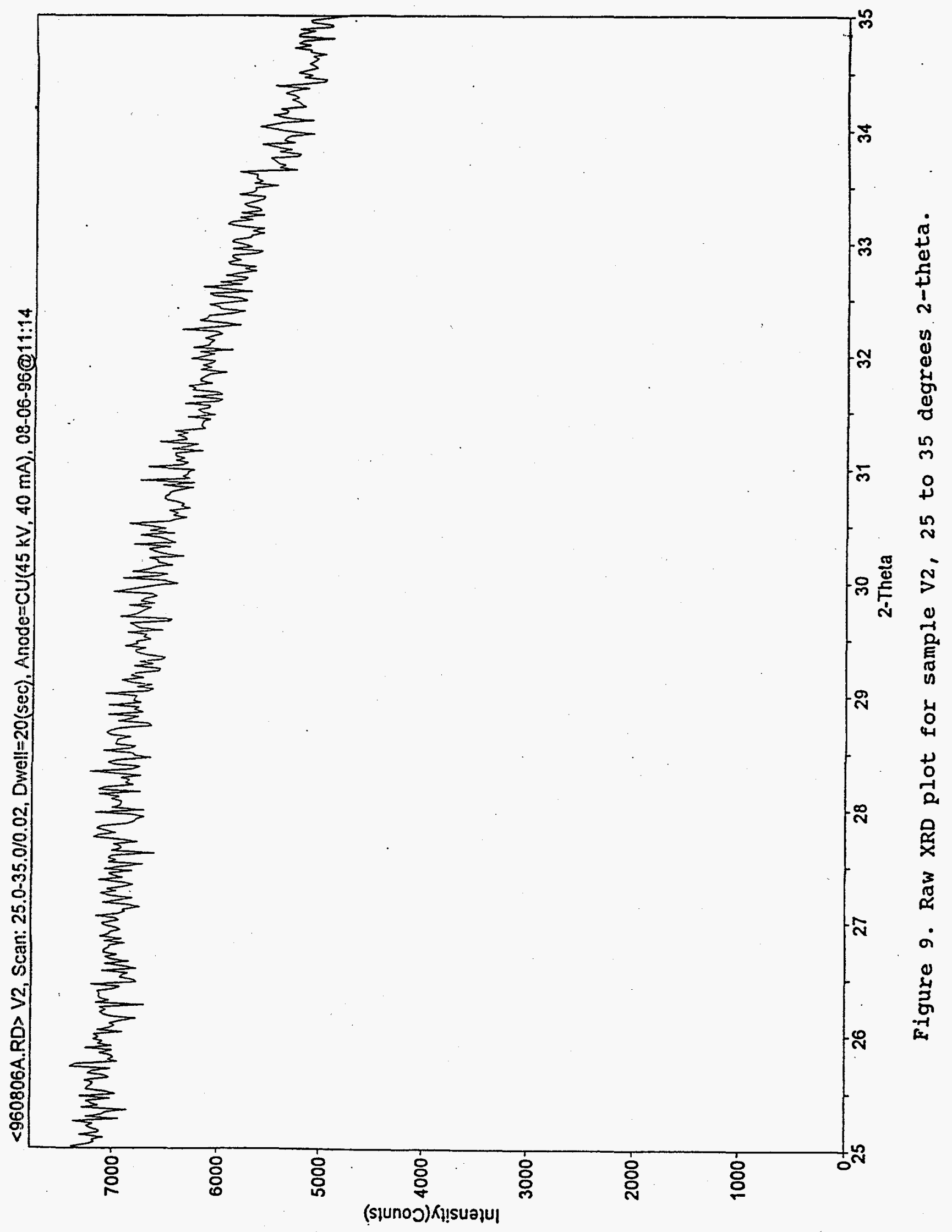




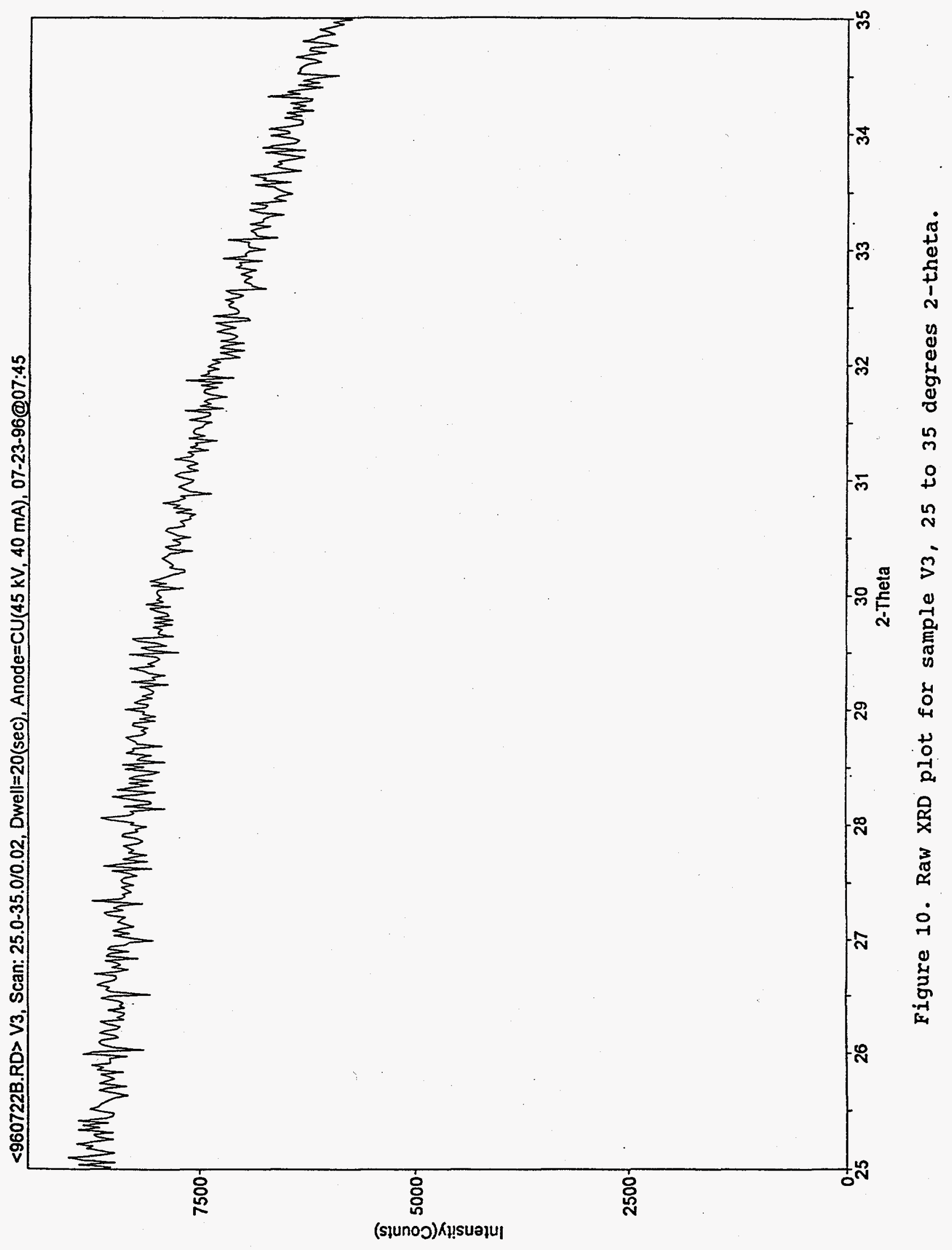




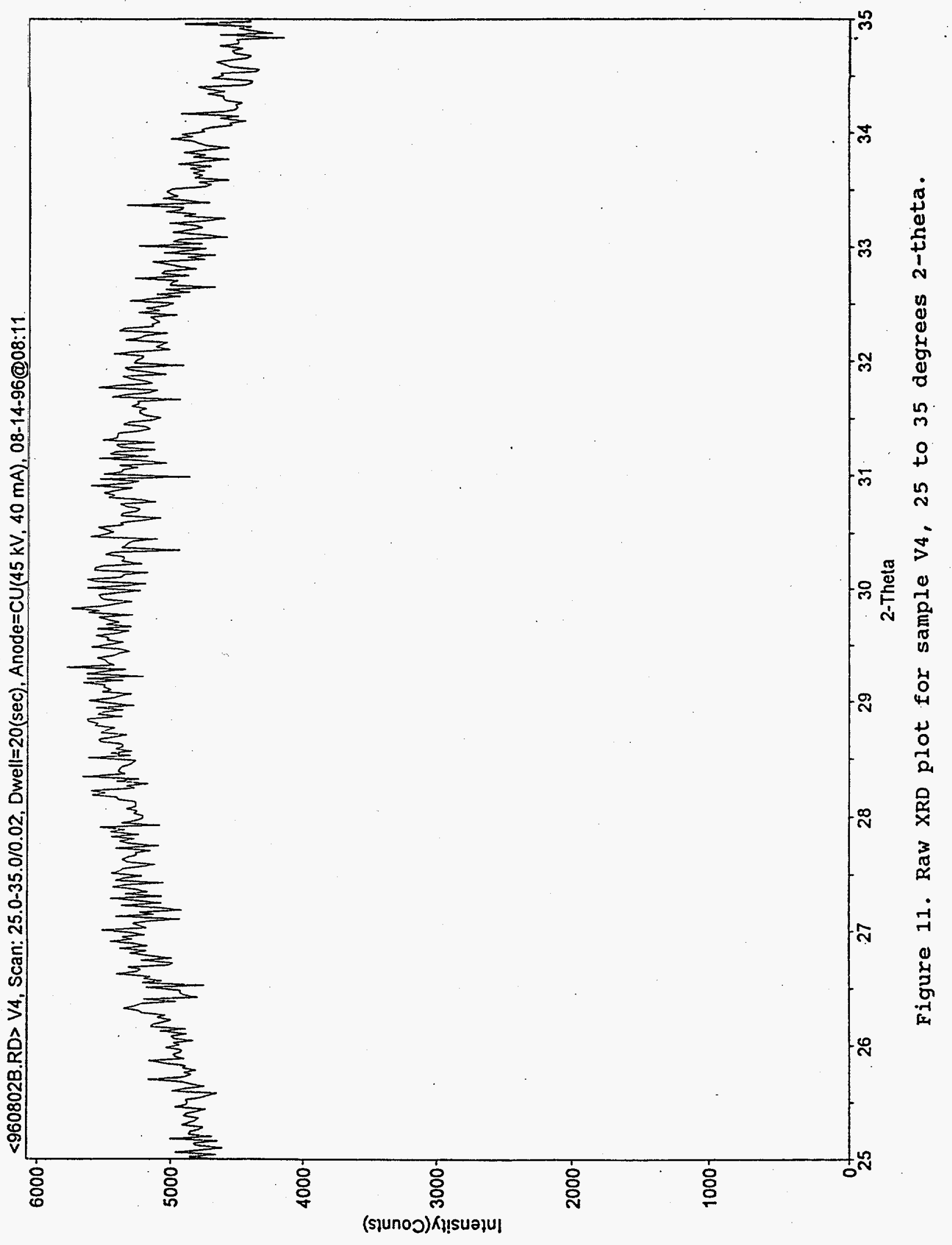

A-14 


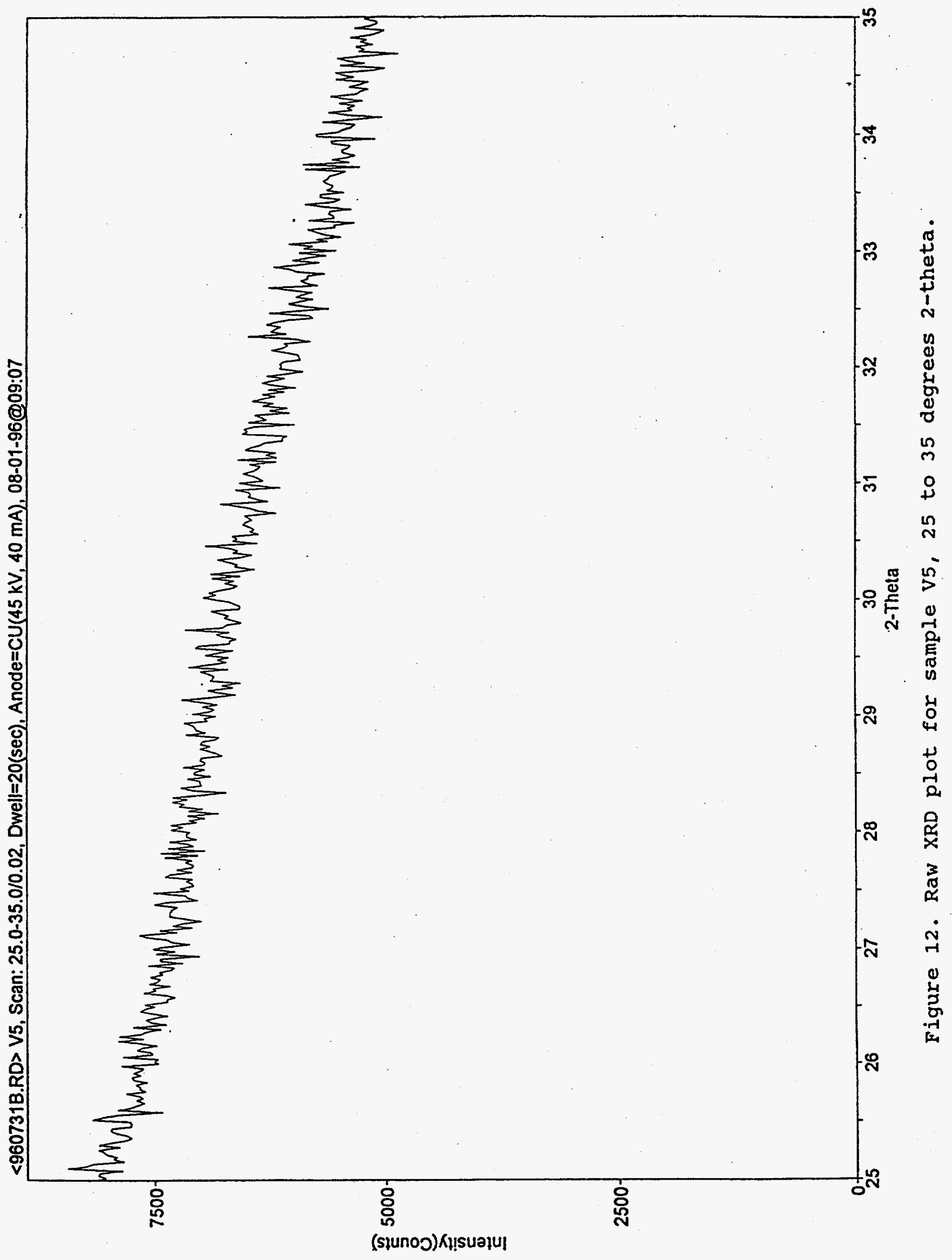




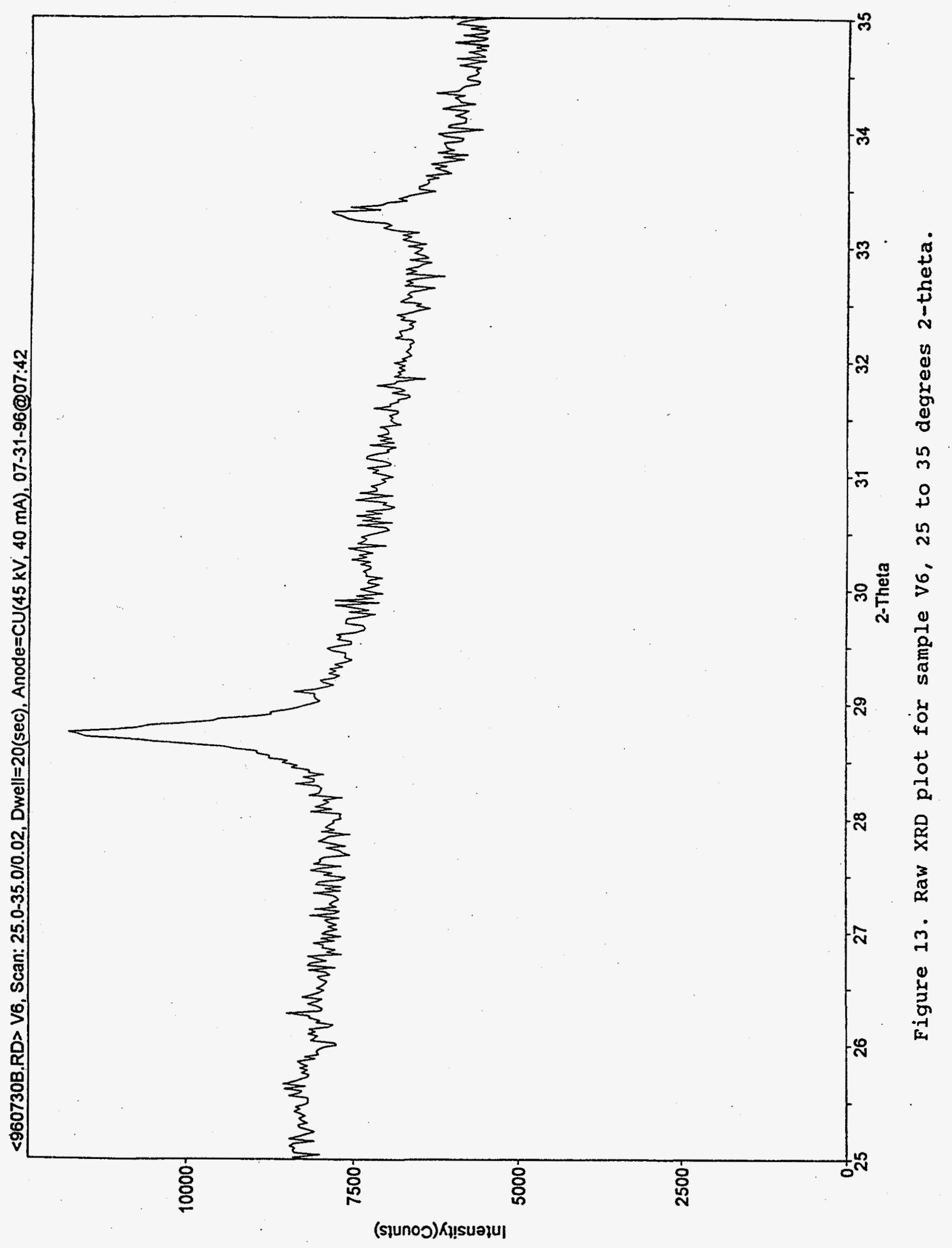

A-16 


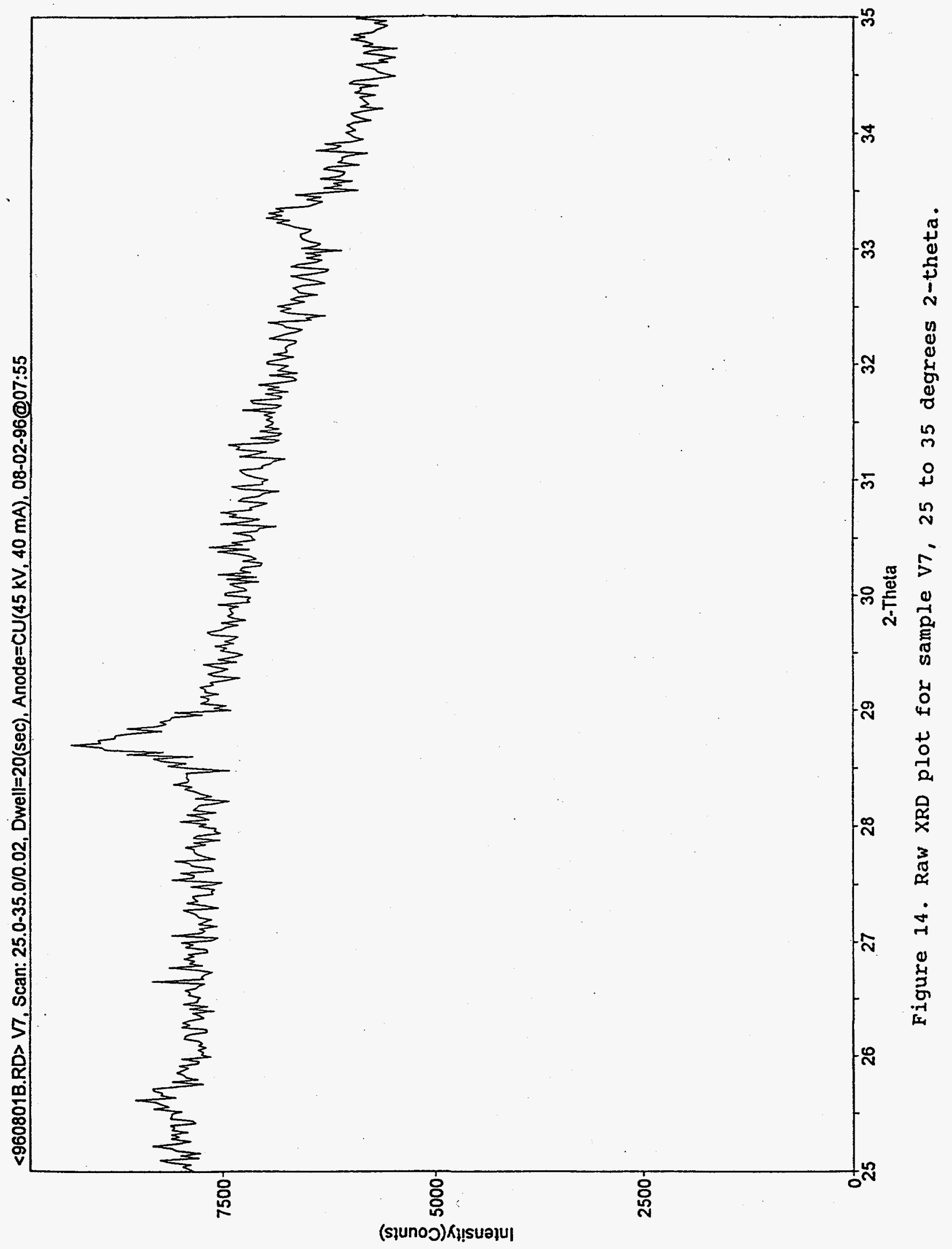




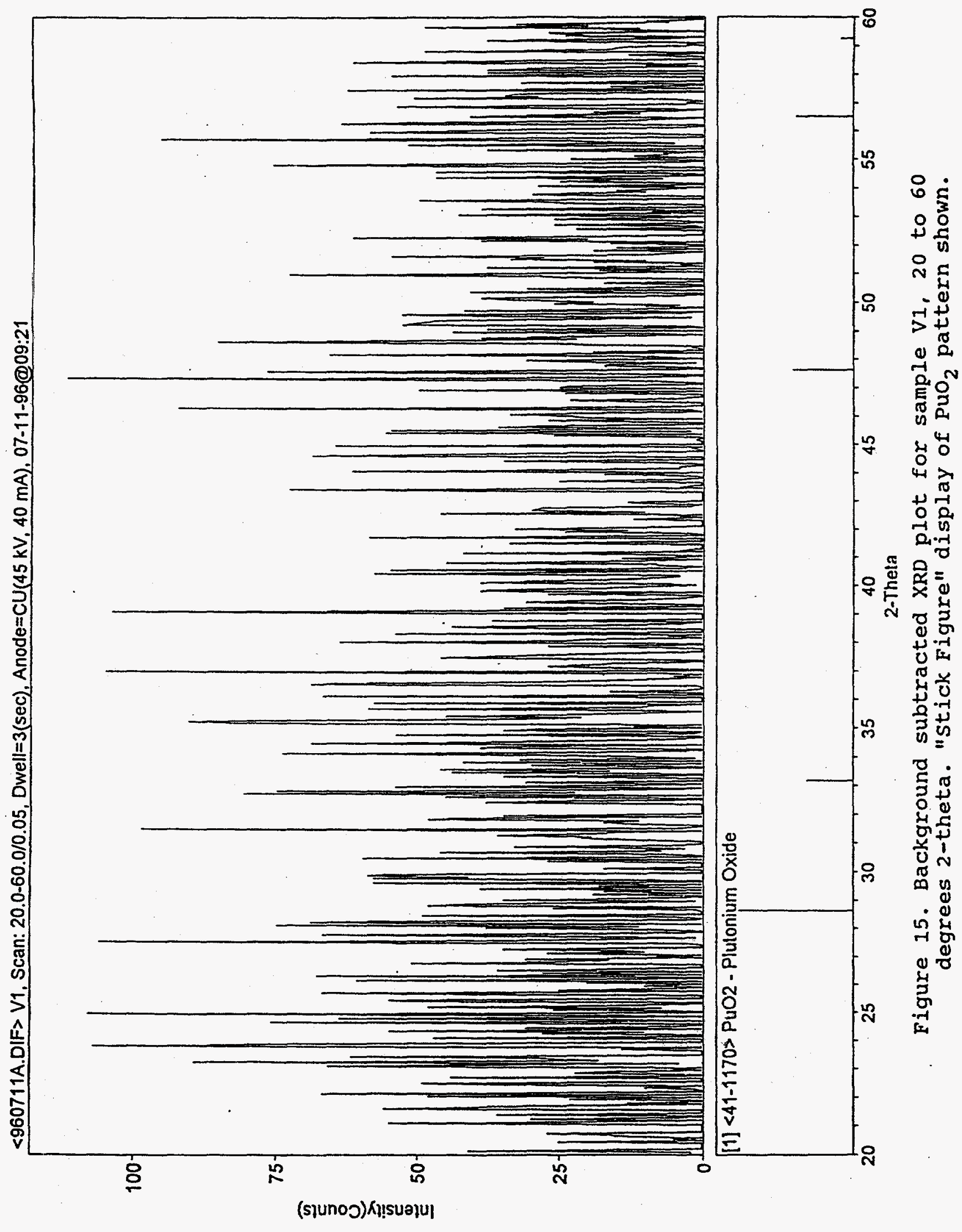




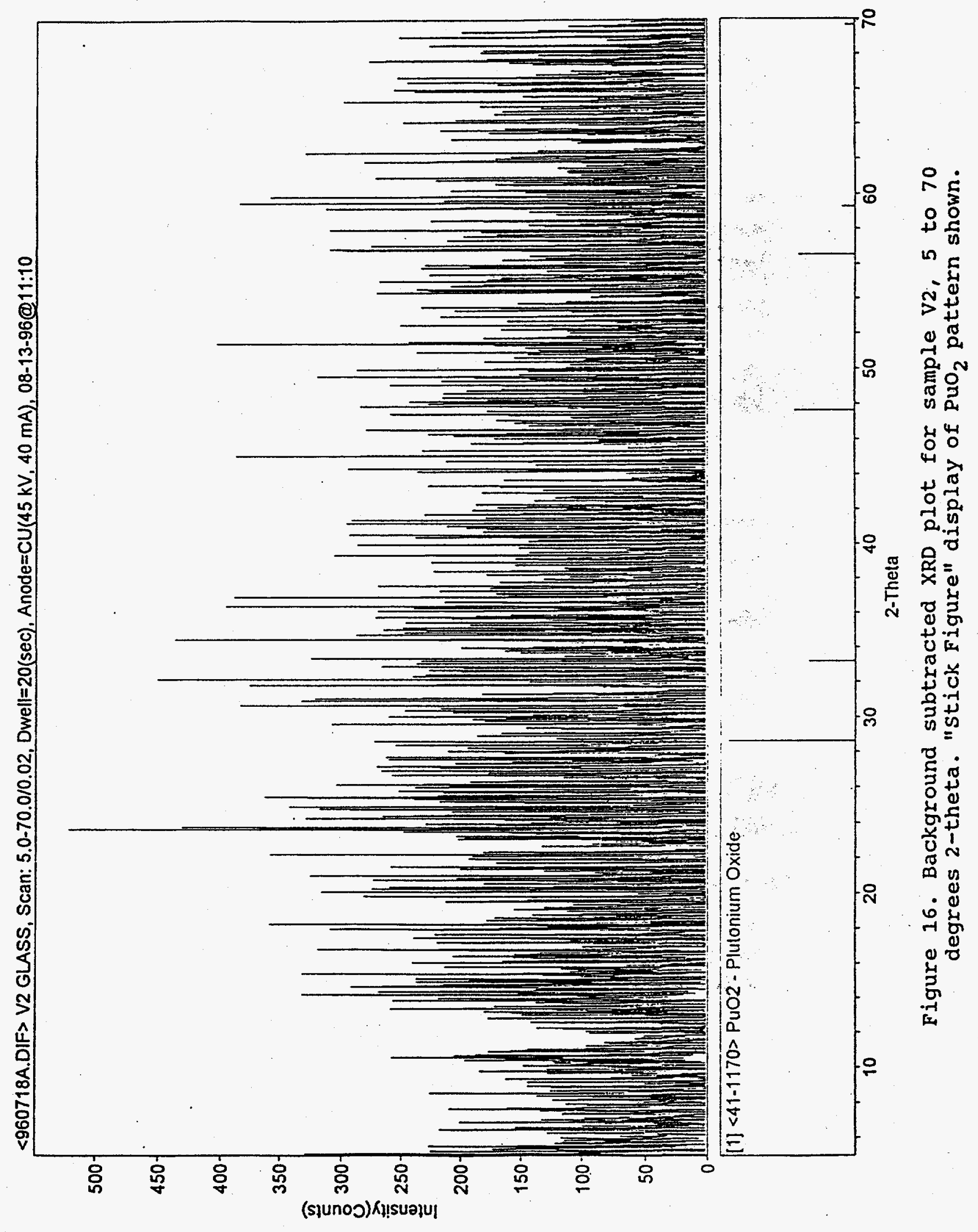




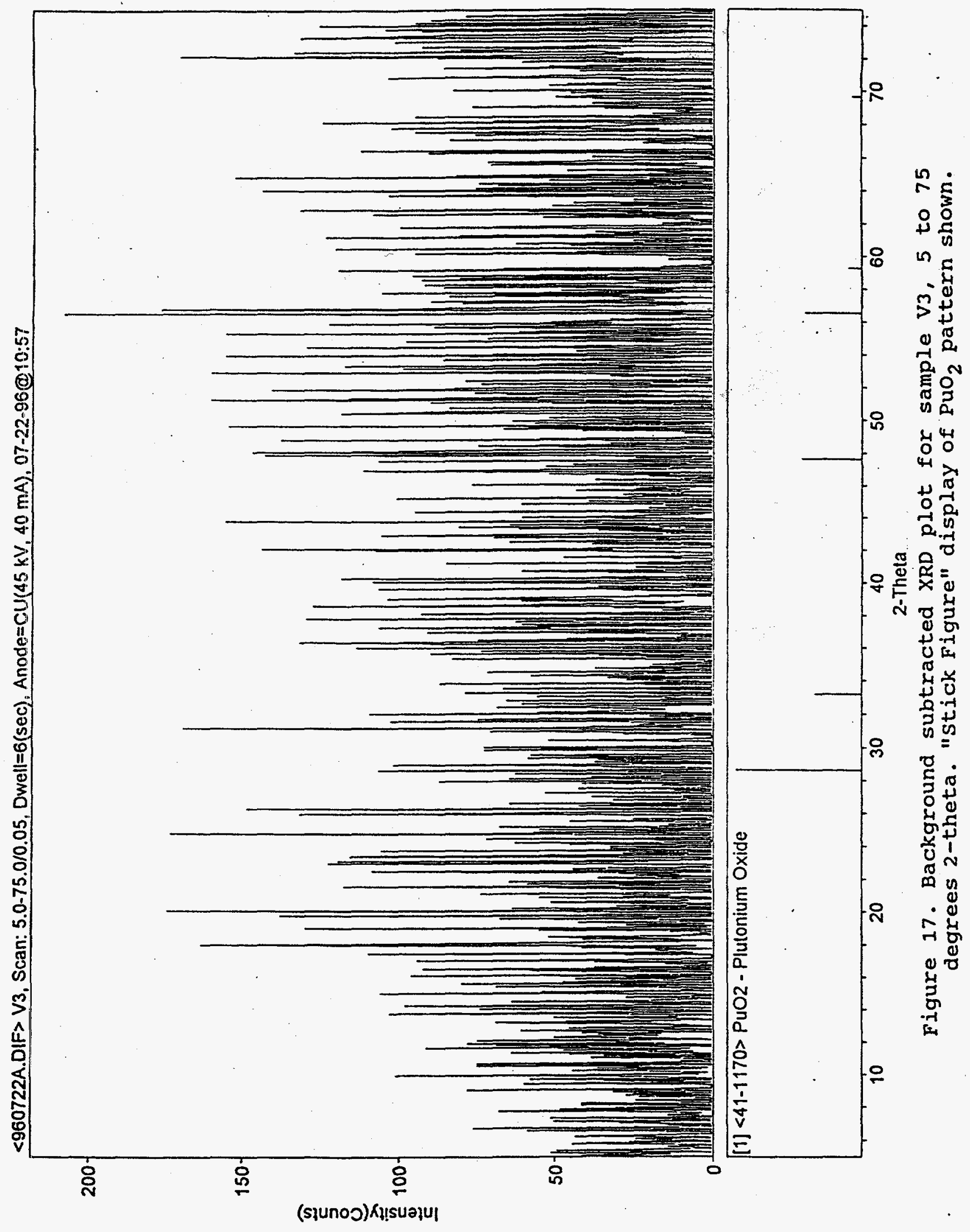




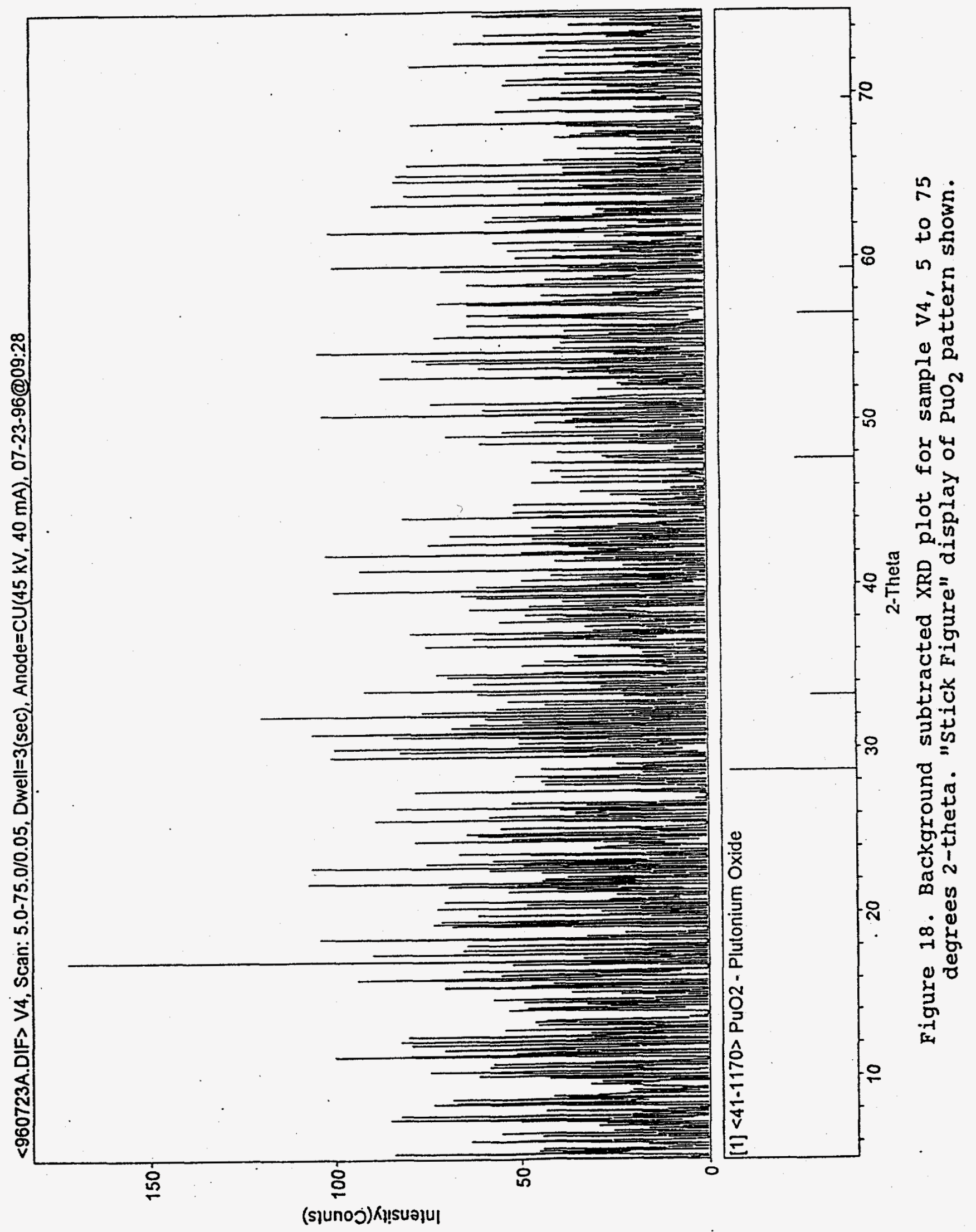




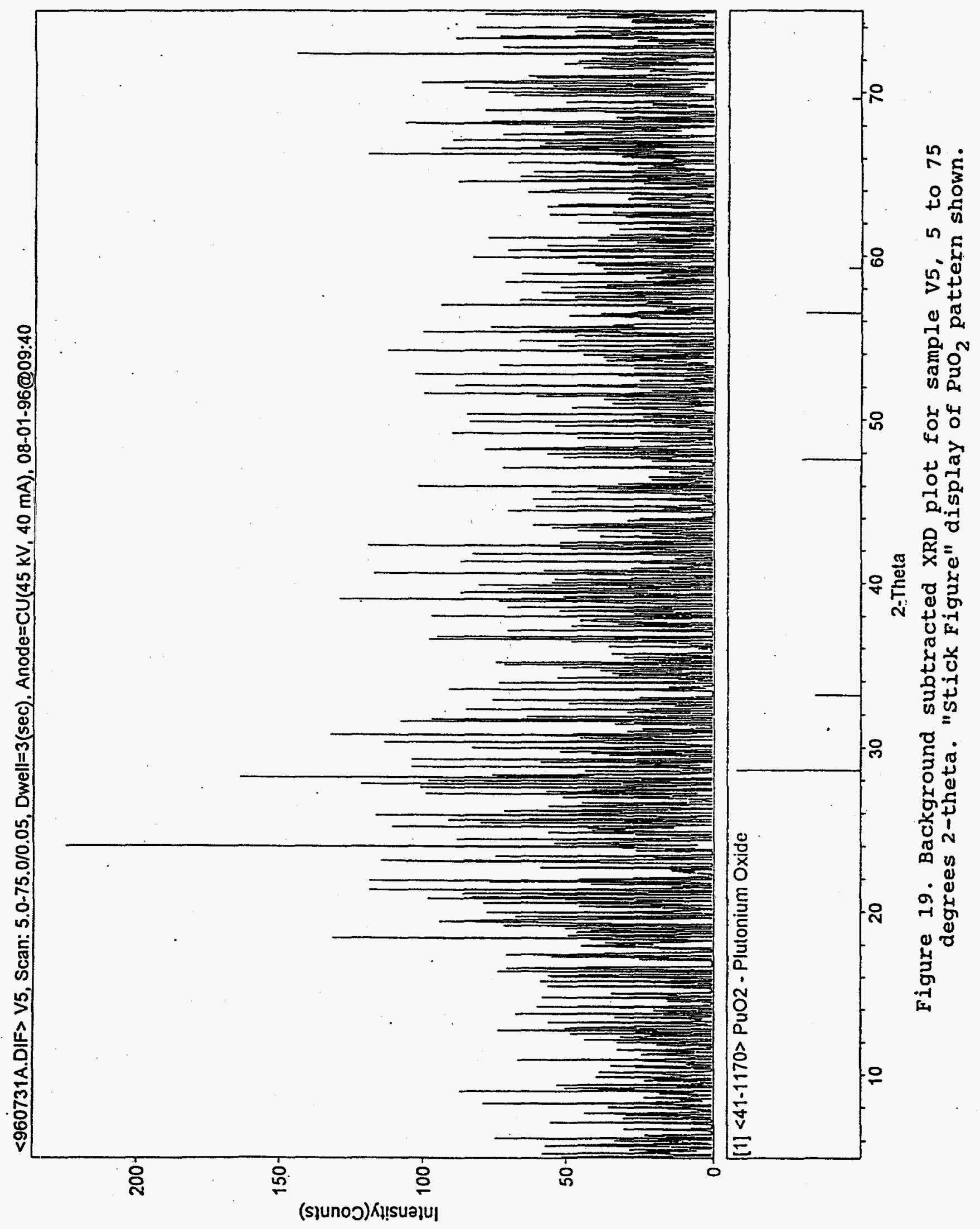




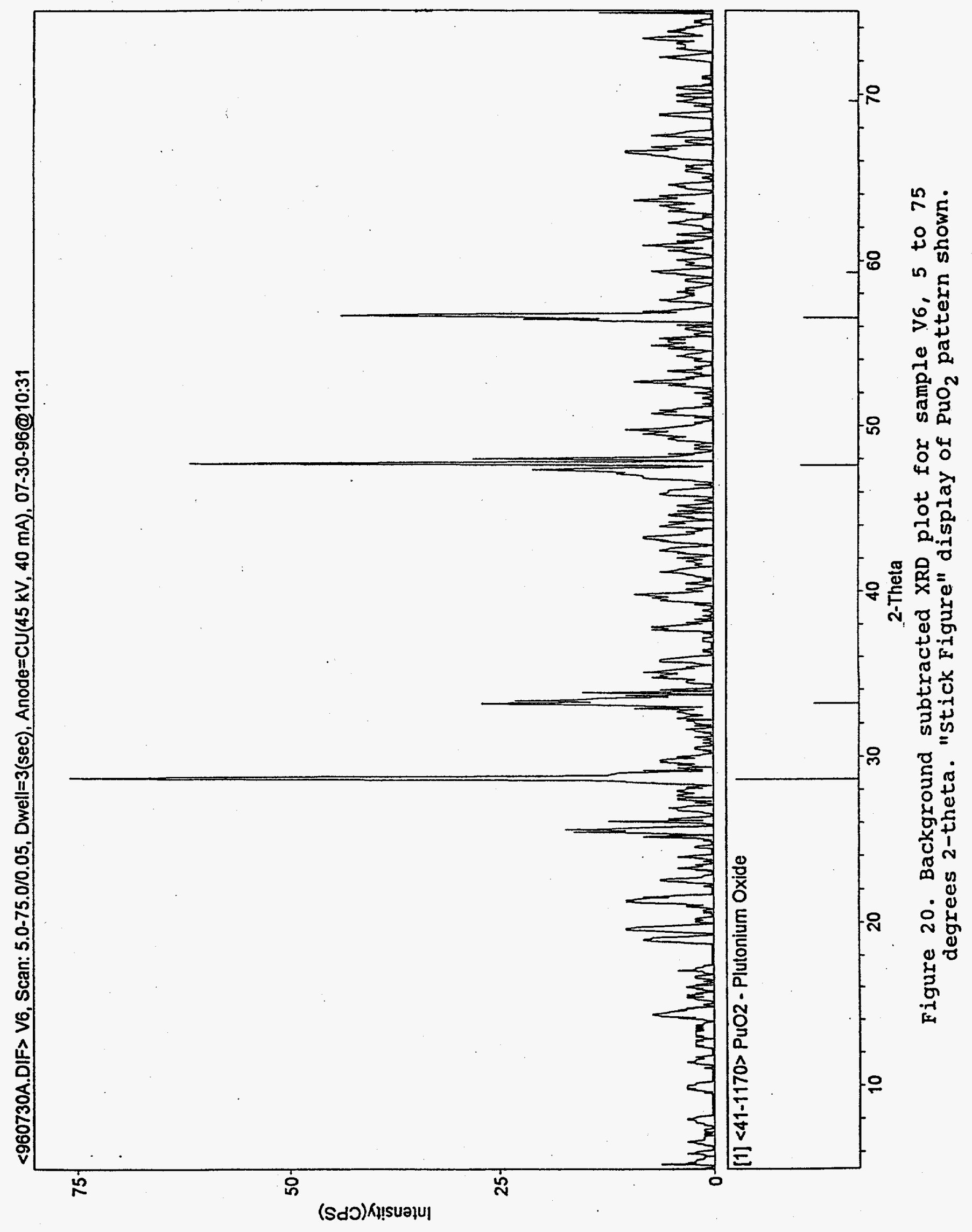




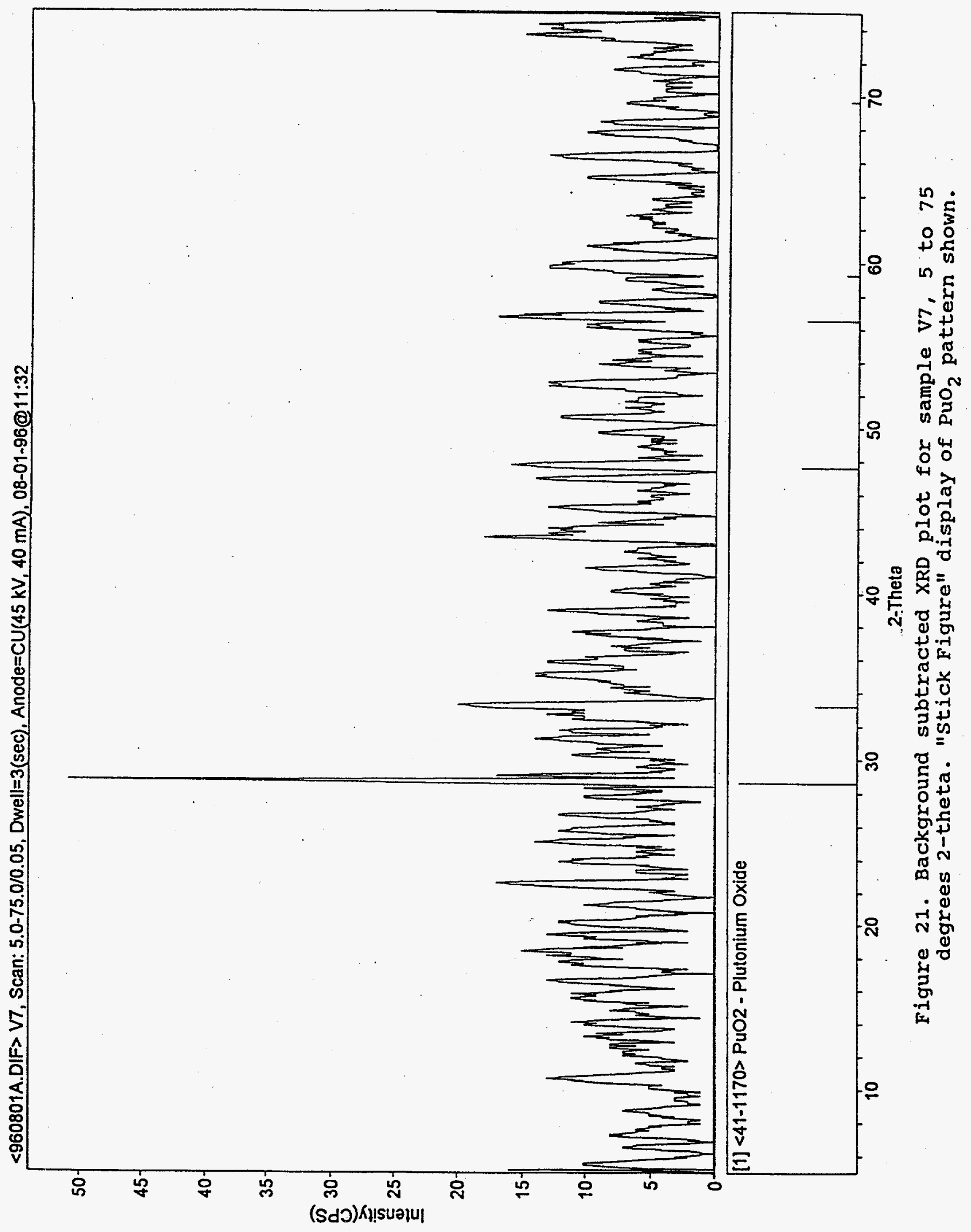




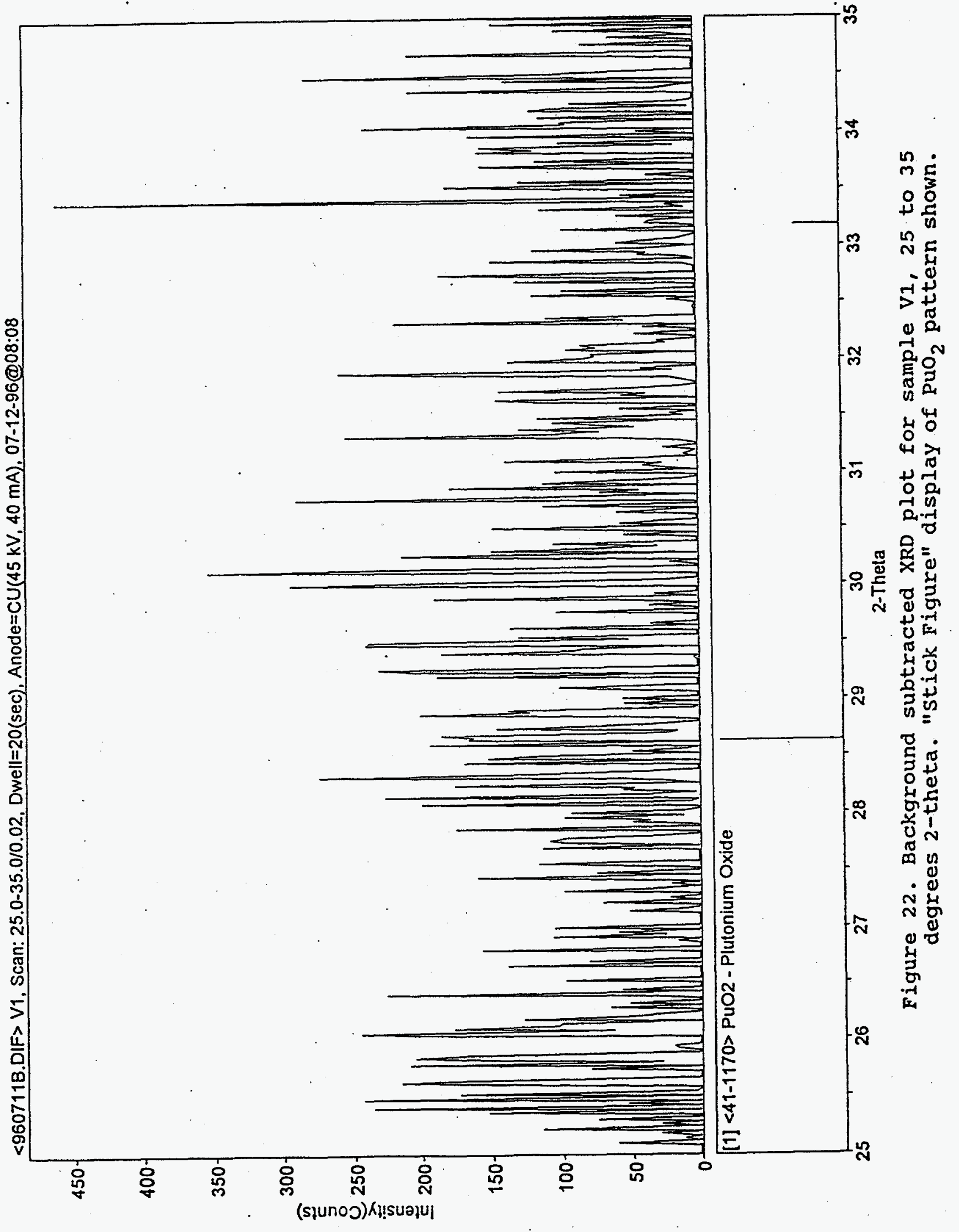




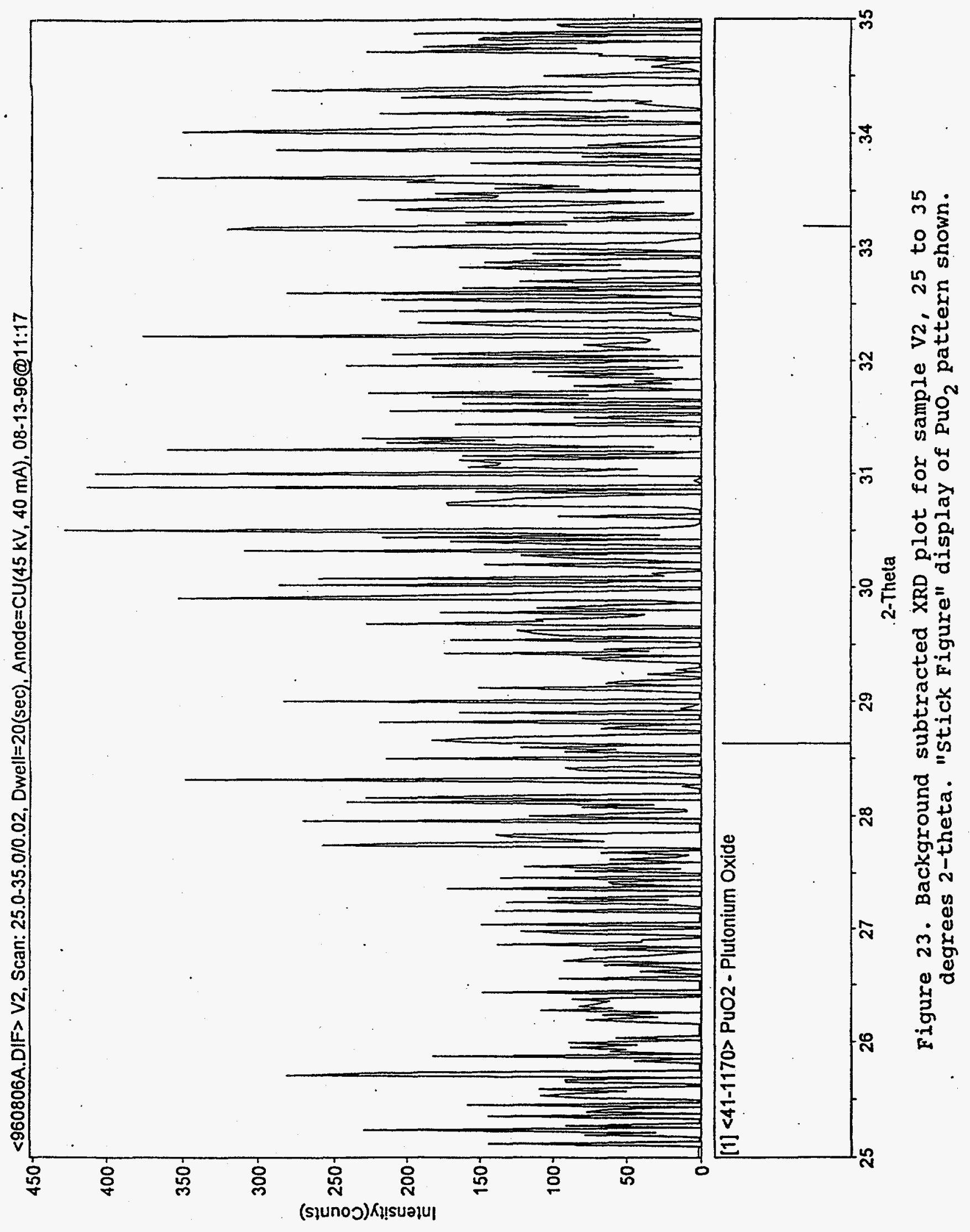




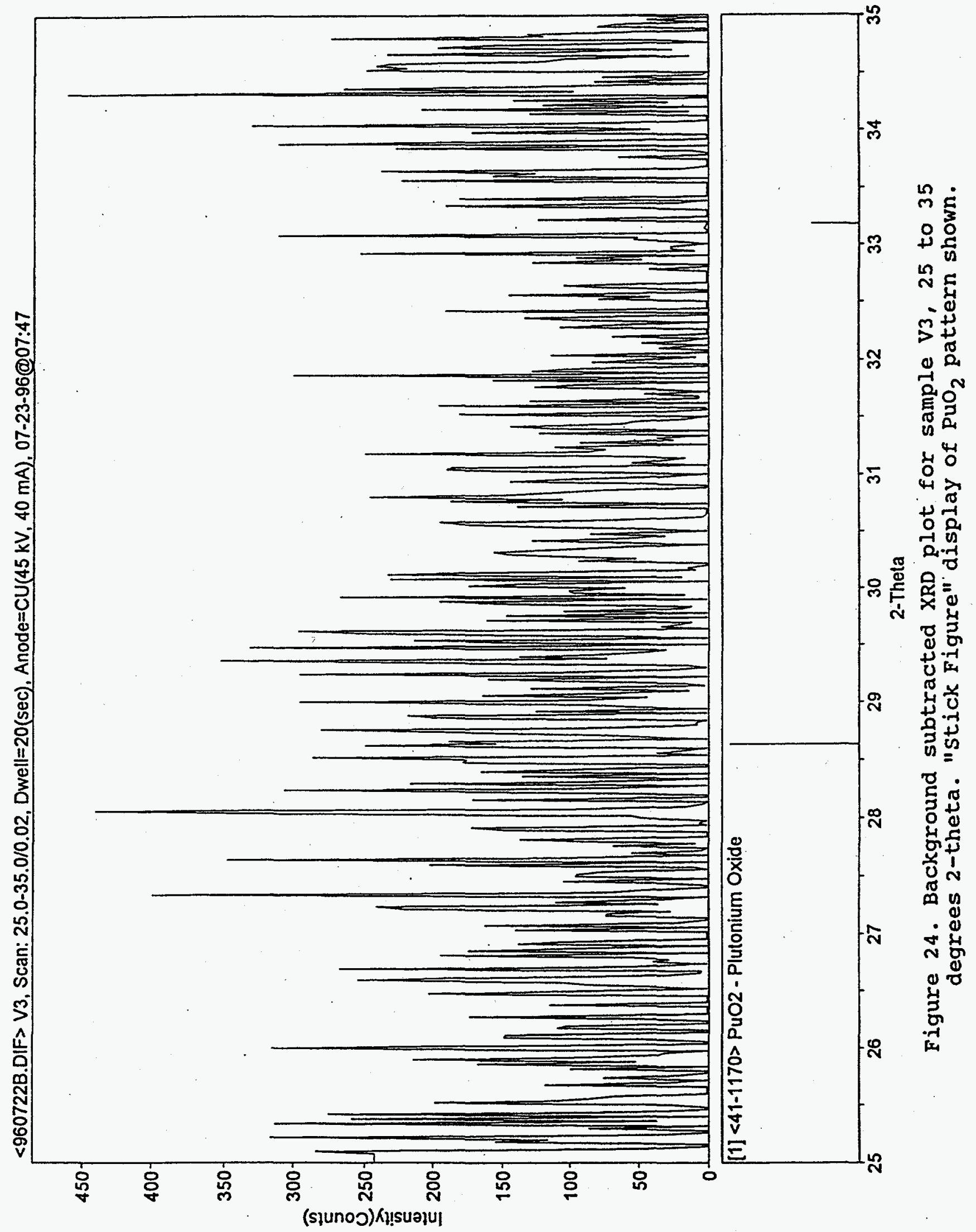




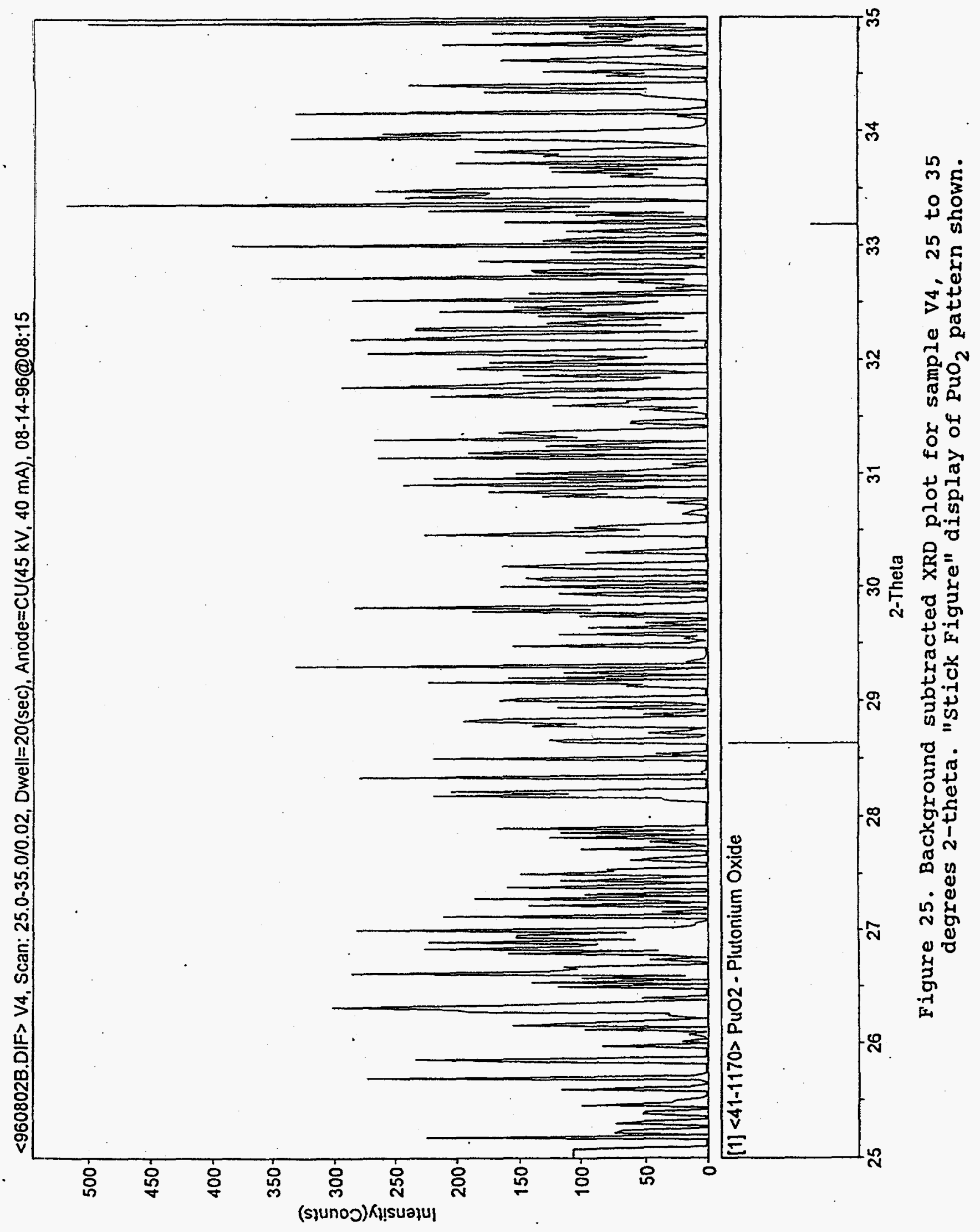




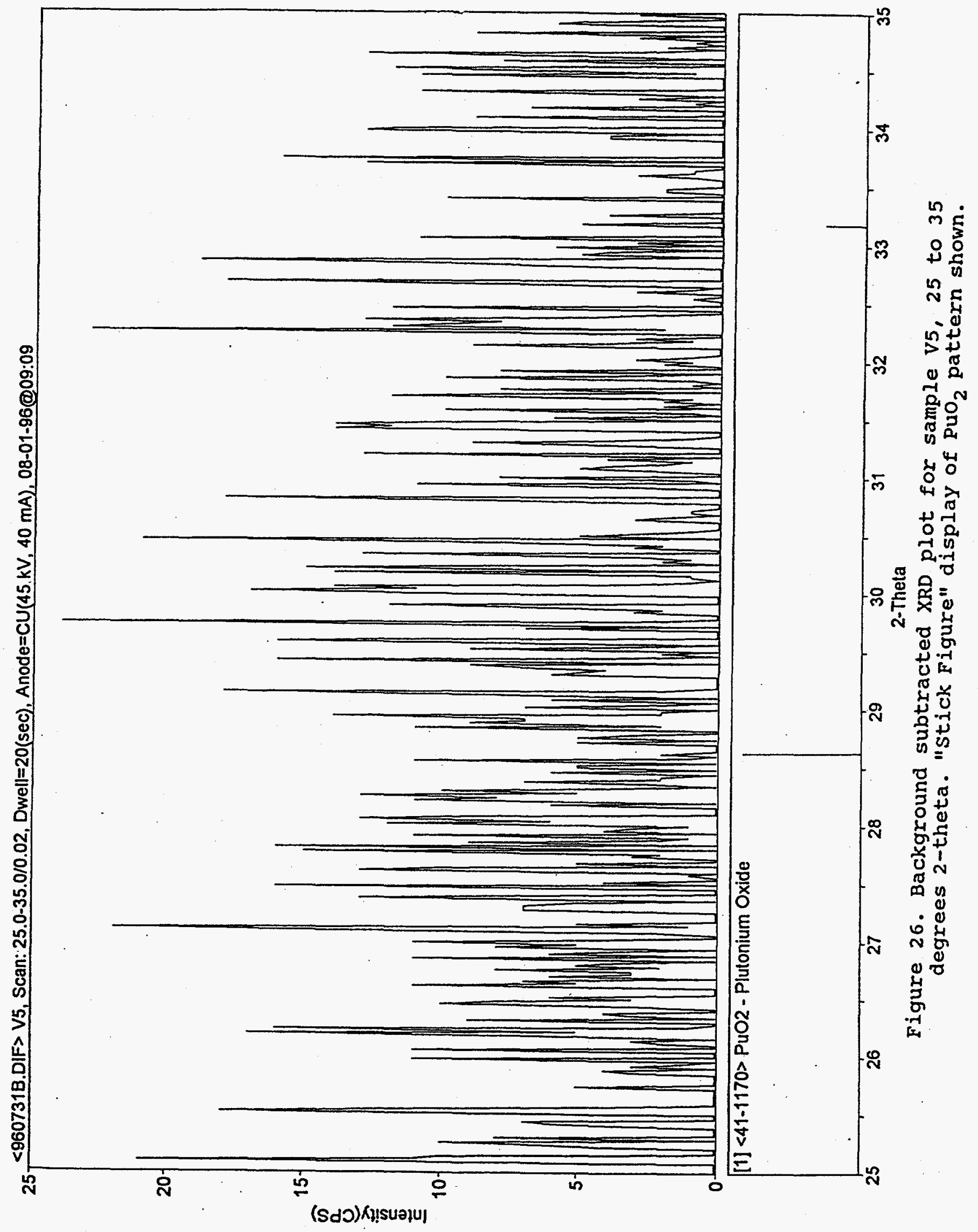




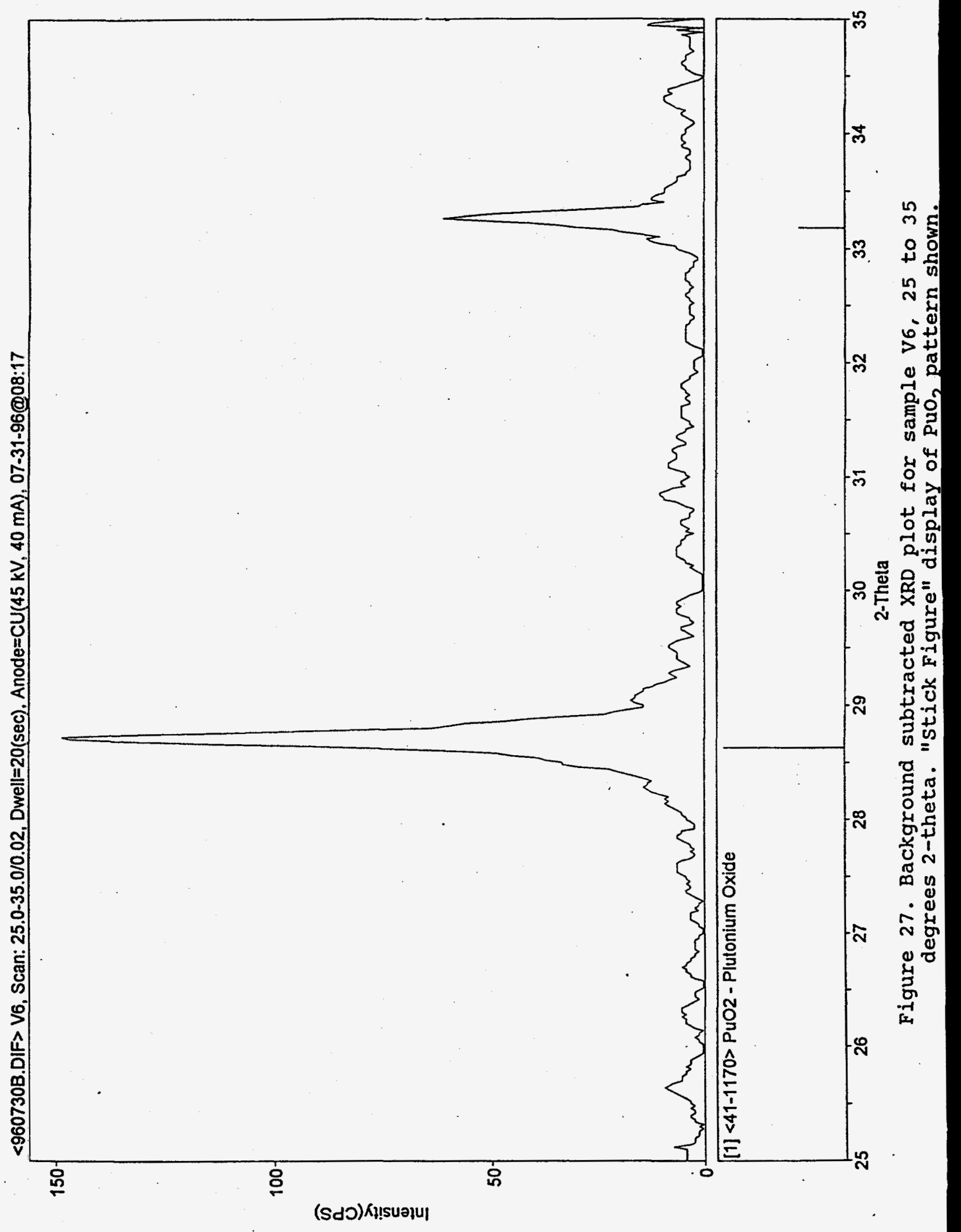



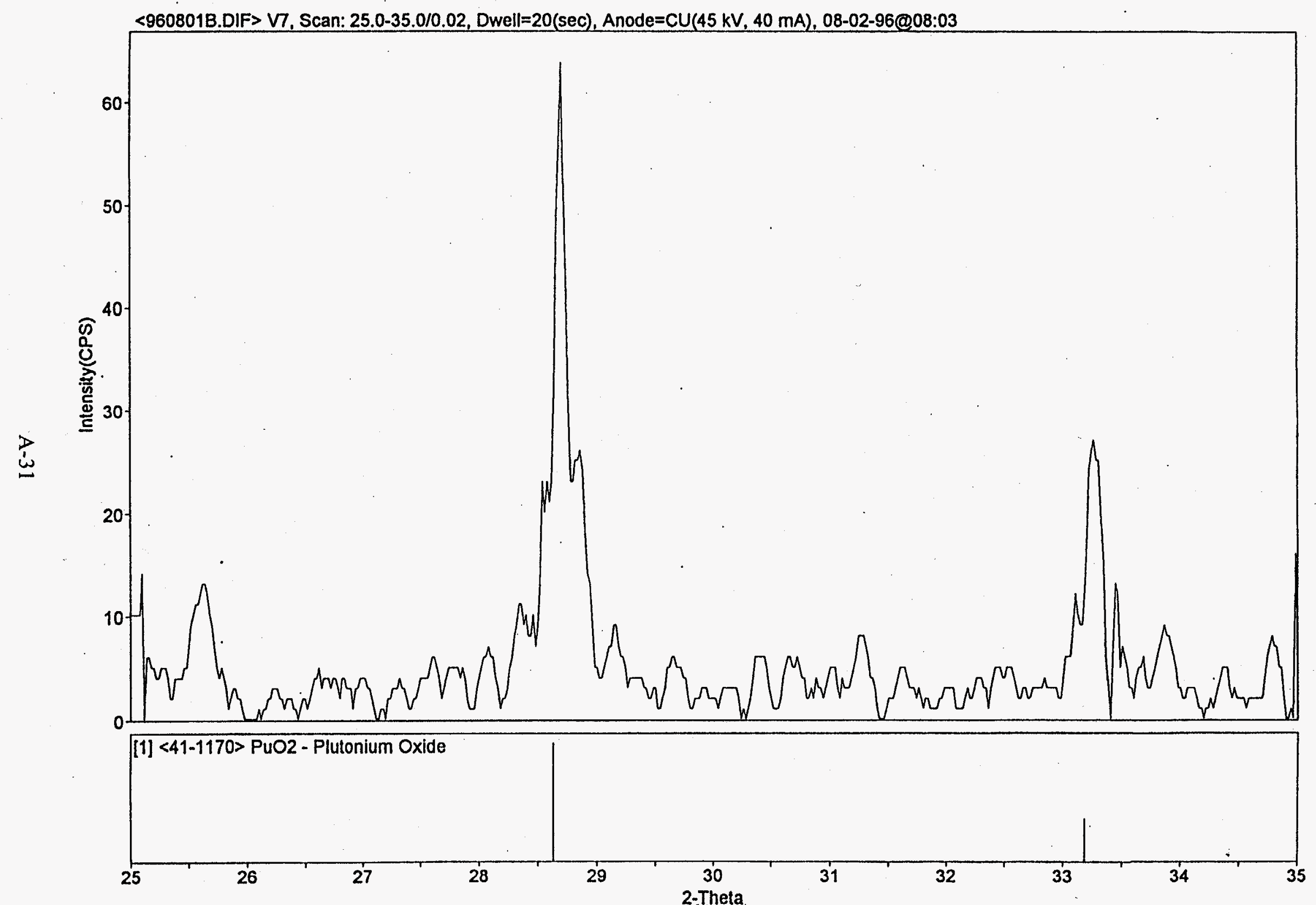

Figure 28. Background subtracted XRD plot for sample V7, 25 to 35 degrees 2-theta. "stick Figure" display of $\mathrm{PuO}_{2}$ pattern shown. 


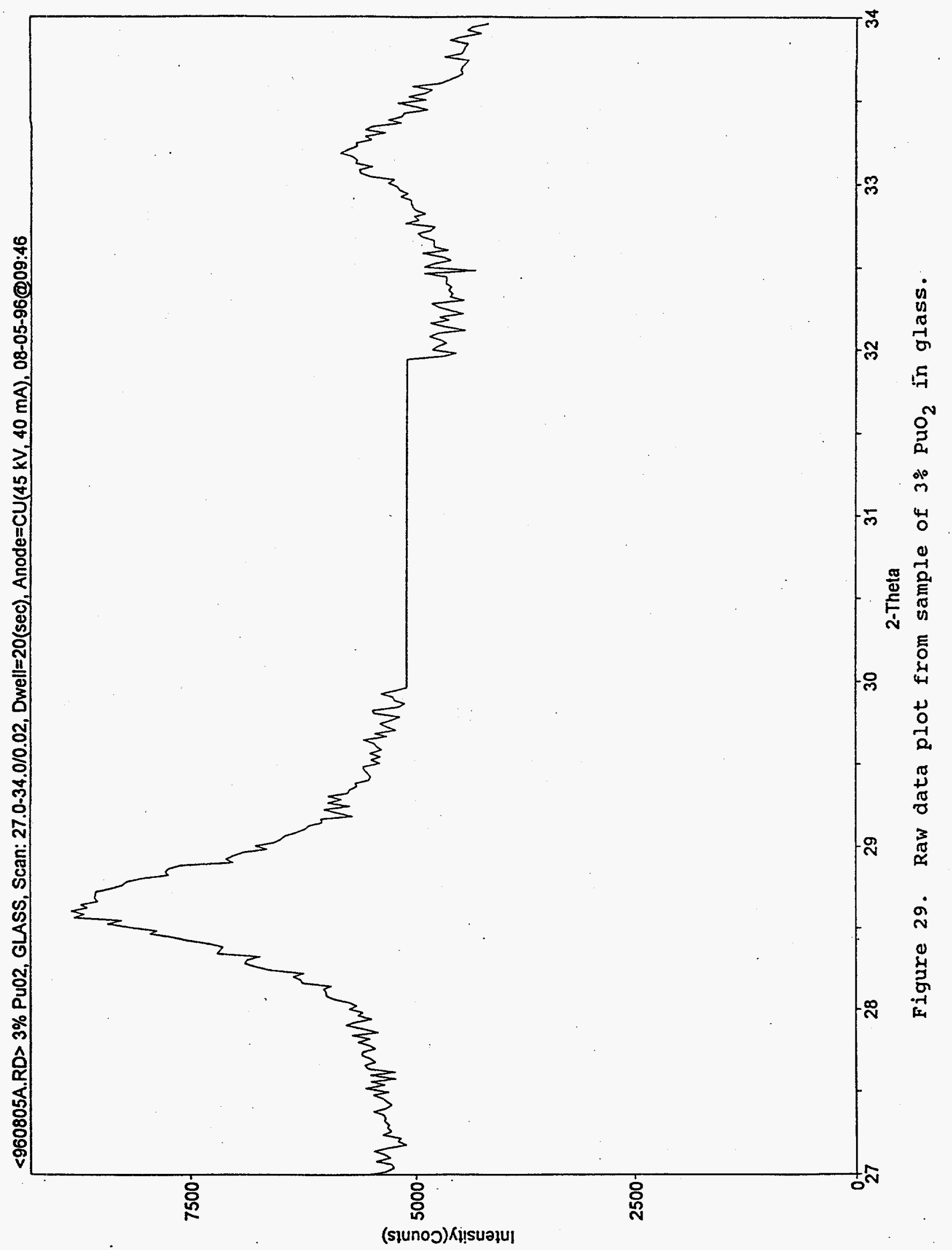

A-32 


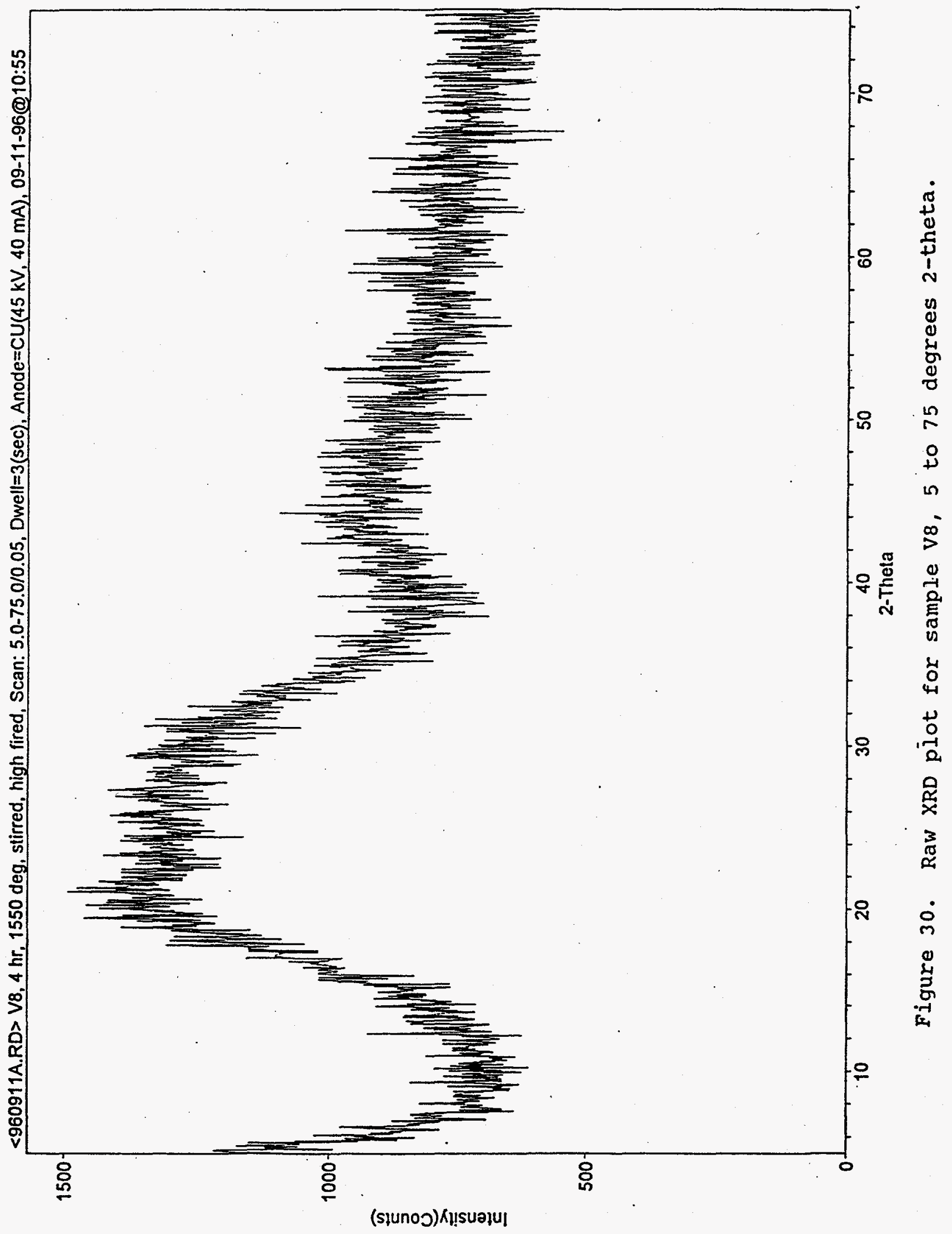




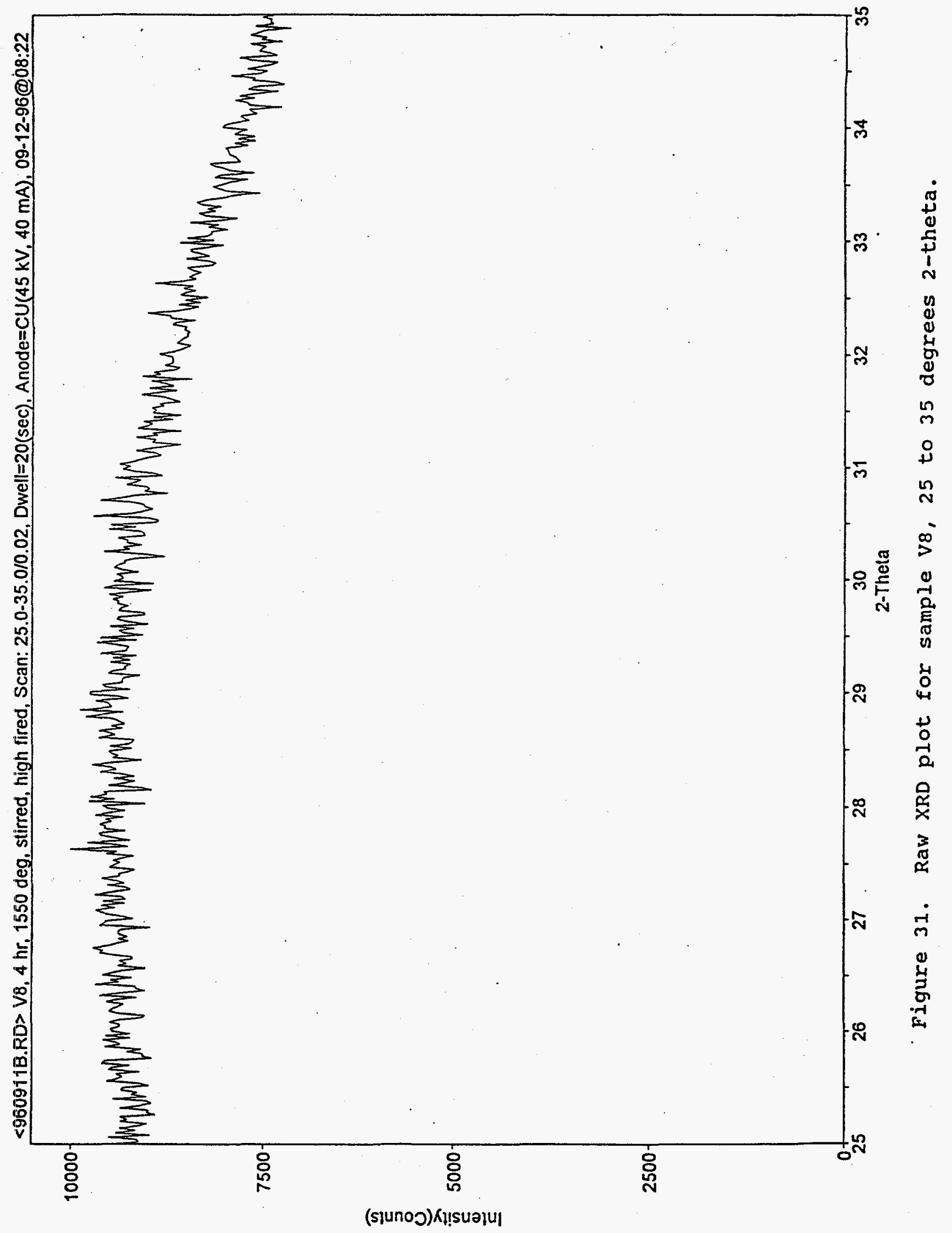




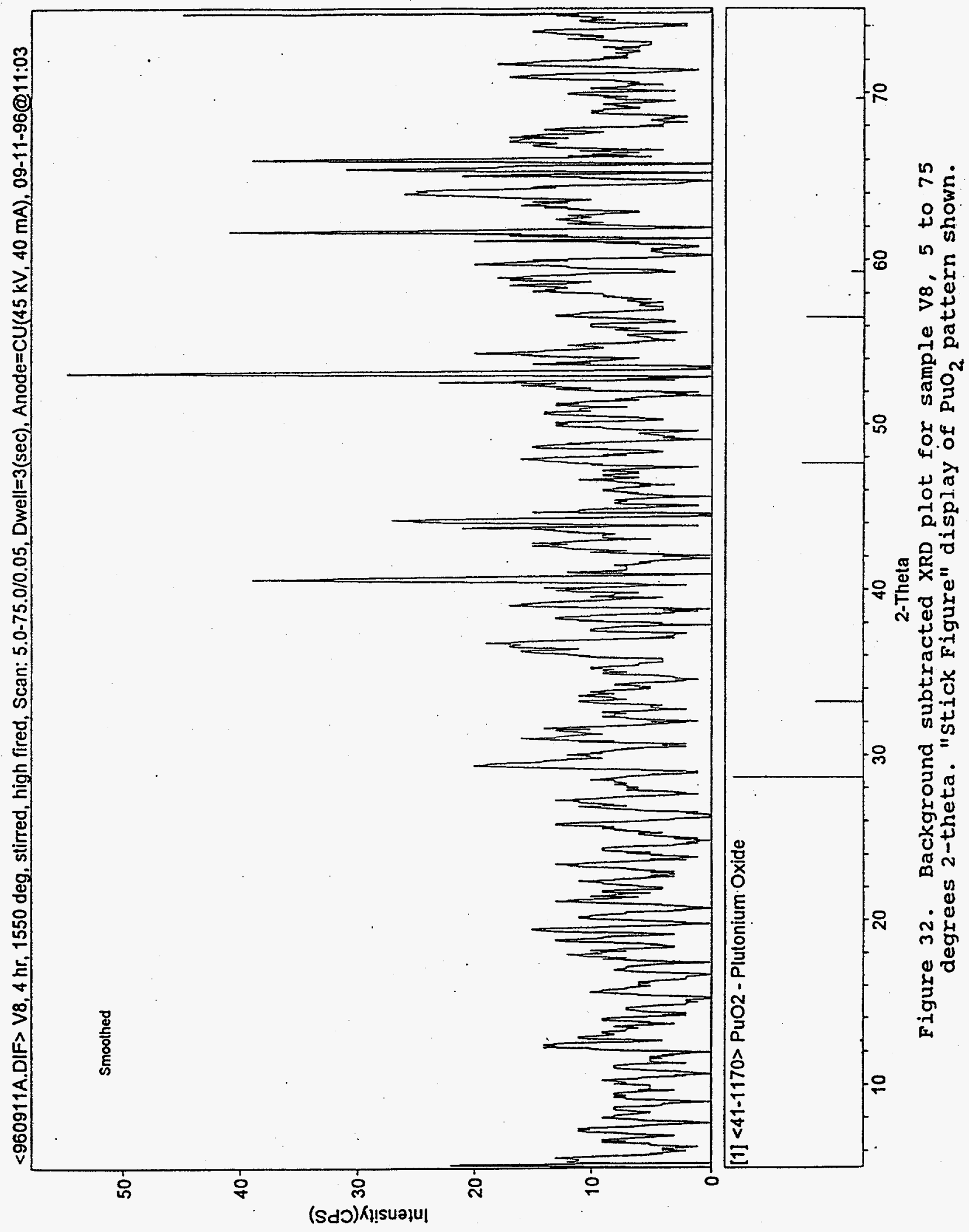




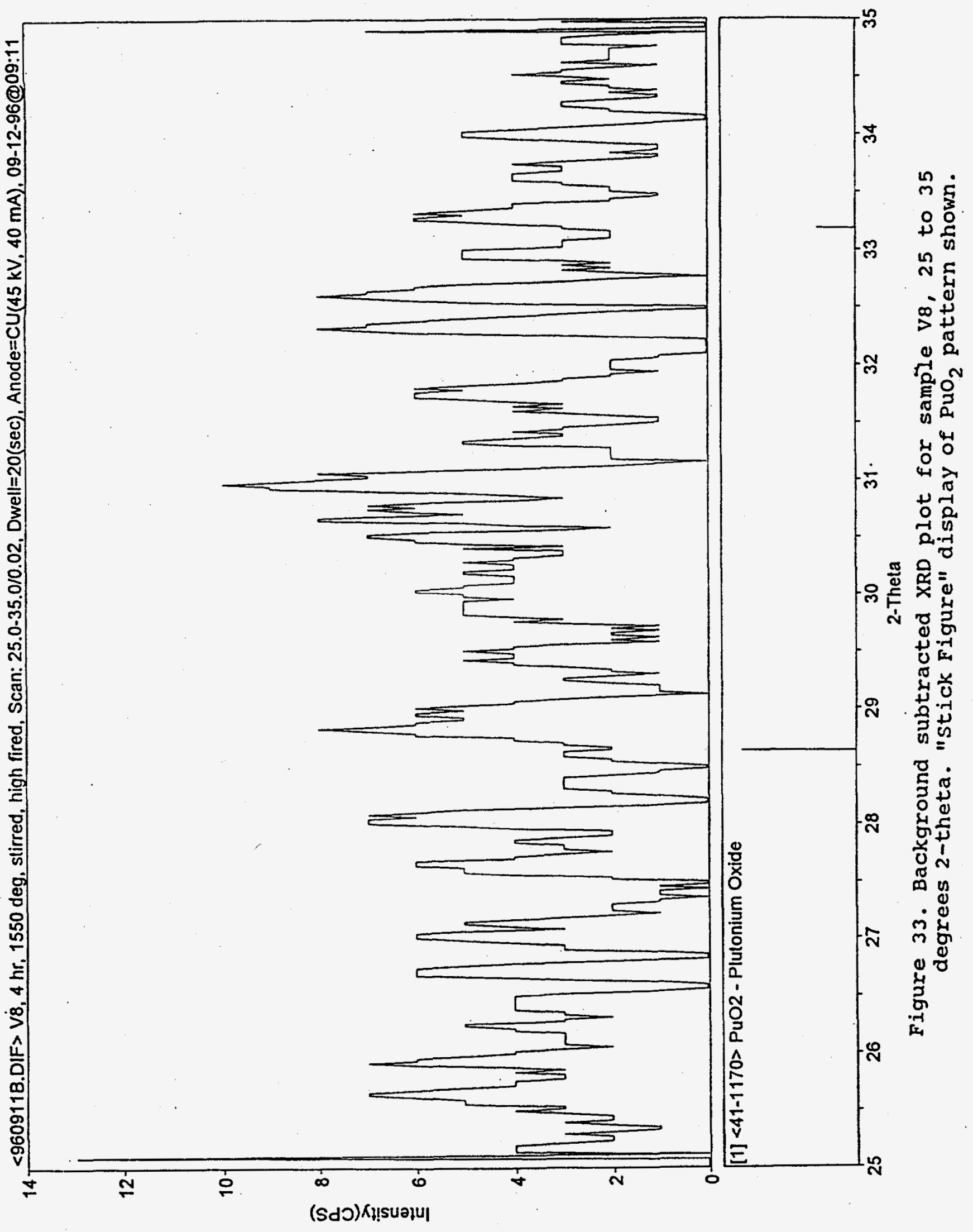




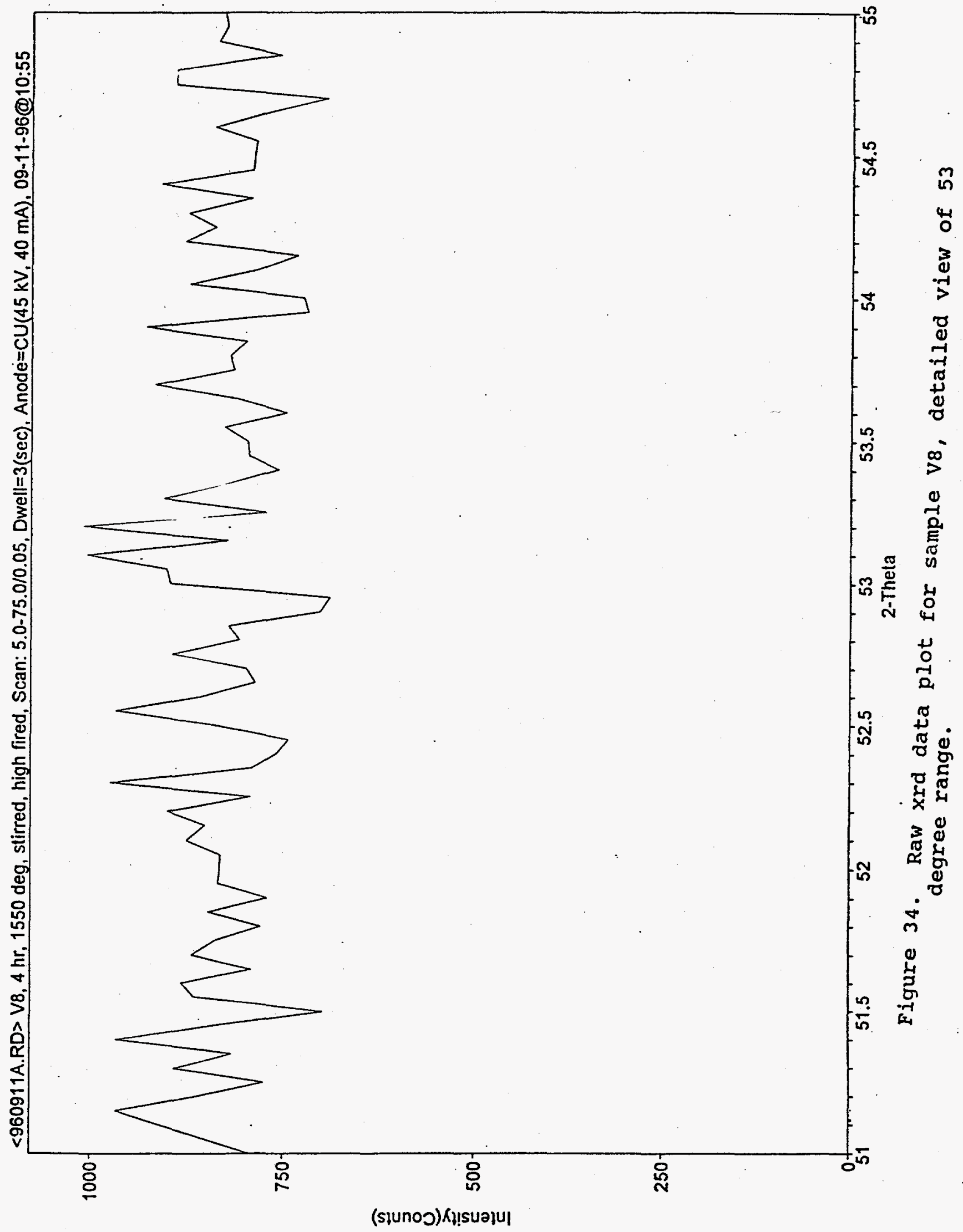




\section{Appendix B}

\section{Inductively Coupled Plasma/Mass Spectroscopy Results}

The following table shows the ICP/MS results from $\mathrm{KOH}$ fused glass samples listed in Table III. The glasses were prepared and analyzed according to the procedures listed in experimental approach section. 


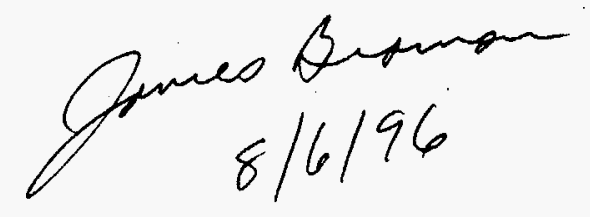

\section{John Vienna Anaylsis}

August 2, 1996 (revised 8/6/96)

\section{DATA REVIEW}

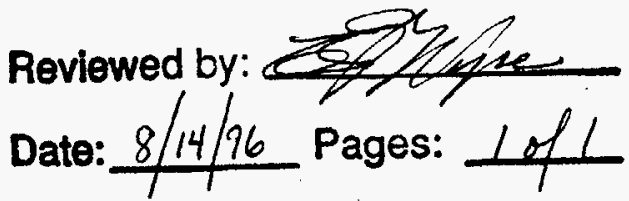

Results are reported in $\mu \mathrm{g} / \mathrm{g}$ (ppm) of glass

The uncertainty of the results is conservatively estimated at $\pm 15 \%$; Al results are suspect due to unsatisfactory spike recovery

\begin{tabular}{|c|c|c|c|c|c|c|c|c|c|c|c|}
\hline $\begin{array}{l}\text { Sample } \\
\text { Number }\end{array}$ & $\begin{array}{l}\text { ICP/MS } \\
\text { Number }\end{array}$ & $\begin{array}{c}\text { Samplo } \\
\text { Wolght (g) }\end{array}$ & $\stackrel{B}{\mu g / g}$ & $\begin{array}{c}\text { Al } \\
\mu g / g\end{array}$ & $\begin{array}{c}\text { Sr } \\
\mu g / g\end{array}$ & $\begin{array}{c}\mathrm{Zr} \\
\mu \mathrm{g} / \mathrm{g}\end{array}$ & $\begin{array}{l}\mathrm{La} \\
\mu \mathrm{g} / \mathrm{g}\end{array}$ & $\begin{array}{l}N d \\
\mu g / g\end{array}$ & $\underset{\mu g / g}{G d}$ & $\begin{array}{c}\mathrm{Pu-230} \\
\mu \mathrm{g} / \mathrm{g}\end{array}$ & $\begin{array}{c}A m-241 \\
\mu g / g\end{array}$ \\
\hline $1 \%$ HNO3 & $6802 a 1$ & & 0.56 & $<1$ & 0.09 & 0.52 & 0.061 & 0.15 & 0.13 & $<0.0001$ & $<0.0001$ \\
\hline $\begin{array}{l}\text { Process Blank } \\
\text { Vienna-1 }\end{array}$ & $\begin{array}{l}6802 \mathrm{a} 14 \\
6802 \mathrm{a} 15\end{array}$ & 0.1496 & $\begin{array}{r}360 \\
28000\end{array}$ & $\begin{array}{r}<1000 \\
(118000)\end{array}$ & $\begin{array}{r}240 \\
17600\end{array}$ & $\begin{array}{r}14 \\
6880\end{array}$ & $\begin{array}{r}9 \\
82600\end{array}$ & $\begin{array}{r}390 \\
90900\end{array}$ & $\begin{array}{r}180 \\
58100\end{array}$ & $\begin{array}{r}<10 \\
76200\end{array}$ & $\begin{array}{l}<10 \\
271\end{array}$ \\
\hline $\begin{array}{l}\text { Vienna-1 Dup. } \\
\text { Vienna-1 + Spike }\end{array}$ & $\begin{array}{l}6802 \mathrm{a} 23 \\
6802 \mathrm{a} 24\end{array}$ & $\begin{array}{l}0.1496 \\
0.1496\end{array}$ & $\begin{array}{r}30100 \\
106000\end{array}$ & $\begin{array}{l}(120000) \\
(217000)\end{array}$ & $\begin{array}{l}19300 \\
89900\end{array}$ & $\begin{array}{r}7020 \\
78700\end{array}$ & $\begin{array}{r}92800 \\
168000\end{array}$ & $\begin{array}{l}106000 \\
178000\end{array}$ & $\begin{array}{r}69500 \\
136000\end{array}$ & $\begin{array}{r}78900 \\
106000\end{array}$ & $\begin{array}{r}280 \pm 30 \\
646\end{array}$ \\
\hline Splke Recovery & & & $114 \%$ & $145 \%$ & $106 \%$ & $107 \%$ & $112 \%$ & $108 \%$ & $99 \%$ & $101 \%$ & $94 \%$ \\
\hline Vienna-2 & $6802 a 16$ & 0.1026 & 32400 & $(117000)$ & 19500 & 7830 & 97200 & 100000 & 67600 & 81100 & 329 \\
\hline Vienna-3 & $6802 a_{17}$ & 0.1421 & 29100 & $(107000)$ & 15800 & 6490 & 78800 & 87300 & 55100 & 76000 & 362 \\
\hline Vienna-4 & $6802 a 18$ & 0.1498 & 31000 & $(119000)$ & 18200 & 7080 & 85400 & 96800 & 59100 & 66500 & 249 \\
\hline Vienna.5 & $6802 a 19$ & 0.1204 & 32600 & $(115000)$ & 18300 & 6480 & 88000 & 94700 & 63400 & 71800 & 262 \\
\hline $\begin{array}{l}\text { CCV results are } \\
\text { 10ppb ICPMS-1 } \\
\text { 10ppb ICPMS-1 }\end{array}$ & $\begin{array}{l}\text { In } \mathrm{ng} / \mathrm{ml} \text { (p) } \\
6802 \mathrm{a} 7 \\
6802 \mathrm{a} 20\end{array}$ & & & & & & $\begin{array}{l}9.41 \\
10.0\end{array}$ & $\begin{array}{l}10.3 \\
8.19\end{array}$ & $\begin{array}{l}10.9 \\
9.74\end{array}$ & & \\
\hline $\begin{array}{l}50 \mathrm{ppb} S \mathrm{Sr} \text {, Al I.V. } \\
50 \mathrm{ppb} \text { Sr, Al I.V. }\end{array}$ & $\begin{array}{l}6802 a 8 \\
6802 a 21\end{array}$ & & & $\begin{array}{l}47.3 \\
45.6\end{array}$ & $\begin{array}{l}52.5 \\
58.5\end{array}$ & & & & & & \\
\hline $\begin{array}{l}\text { 2ppb Pu-239 } \\
\text { 2ppb Pu-239 } \\
\text { 2ppb Pu-239 }\end{array}$ & $\begin{array}{l}6705 a 4 \\
6705 a 16 \\
6805 a 26 \\
\end{array}$ & & & & & & & & & $\begin{array}{l}1.94 \\
2.02 \\
2.21\end{array}$ & \\
\hline $\begin{array}{l}0.03 \mathrm{ppb} \text { Am-241 } \\
0.03 \mathrm{ppb} \text { Am-241 } \\
0.3 \mathrm{ppb} \text { Am-241. }\end{array}$ & $\begin{array}{l}6705 a 4 \\
6705 a 16 \\
6805 a 25\end{array}$ & & & & & & & & & & $\begin{array}{r}0.029 \pm 0.005 \\
0.039 \pm 0.019 \\
0.266\end{array}$ \\
\hline
\end{tabular}




\section{Appendix C}

\section{Radiochemical Analysis Results}

The following tables show the alpha and gamma energy results from the starting Pu Nitrate feed solution and alpha energy and mass spectroscopy results from KOH fused glass samples listed in Table III. The glasses were prepared and analyzed according to the procedures listed in the experimental approach section. 
Battelle Pacific Northwest National Laboratory

Analytical Chemistry Laboratory

Radiochemistry Group - 325 Bldg.

Client: MJ Schweiger/D Haggard

WP \#: K45603

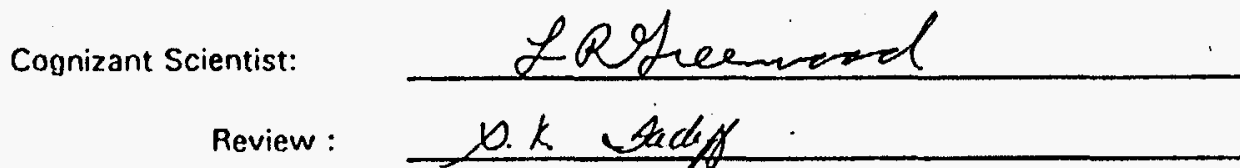

Date: $\frac{7-3-96}{7 / 3 / 96}$

Measured Activities (uCi/ml)

$\stackrel{p}{+}$

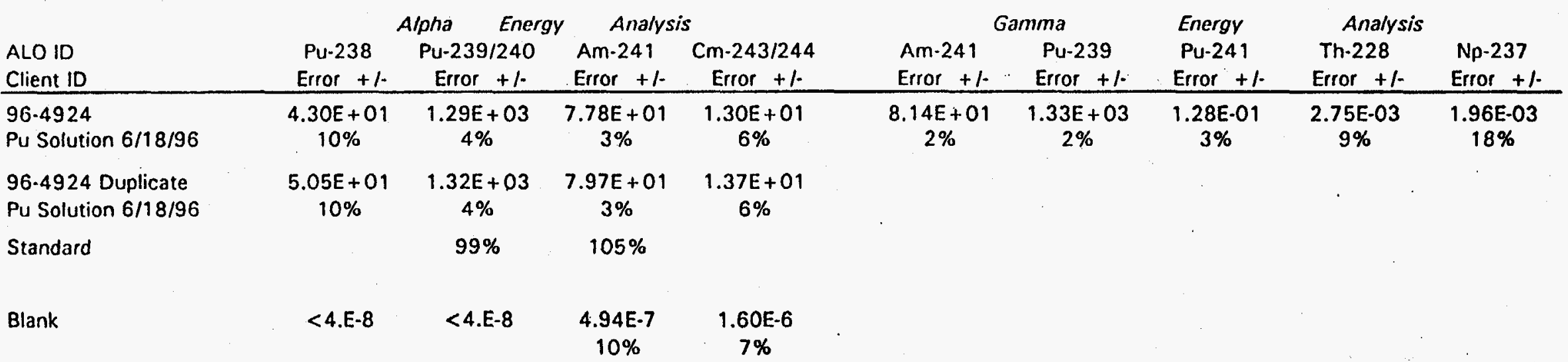

Notes: Pu-241 was detected via the short-lived daughter U-237. Np-237 identification is uncertain since only one gamma line was detected. 


\begin{tabular}{|c|c|c|c|c|c|c|c|c|}
\hline Calclulation sl & eet for & $\%$ & $\mathrm{PuO} 2$ & 271 & grams & Pur & 487 & is \\
\hline $\mathrm{t} 1 / 2$ & 87.7 & 24480 & 6560 & 12.4 & $3.75 E+05$ & $4.33 E+02$ & rears. & \\
\hline sample & Pu238 & Pu239 & Pu240 & Pu241 & Pu242 & Am241 & & \\
\hline Pu\#1 & $3.47 E+07$ & $1.68 \mathrm{E}+08$ & $6.46 E+07$ & $1.92 E+08$ & $6.05 E+05$ & $1.31 \mathrm{E}+07$ & $\mathrm{dpm}$ & 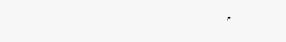 \\
\hline Pu\#2 & $3.53 E+07$ & $1.80 E+08$ & $6.78 E+07$ & $1.98 E+08$ & $6.08 E+05$ & 07 & $\mathrm{dpm}$ & \\
\hline Pu\#3 & $3.67 E+07$ & $1.51 E+08$ & $7.06 E+07$ & $1.92 E+08$ & $6.34 E+05$ & $1.46 \mathrm{E}+07$ & $\mathrm{dpm}$ & \\
\hline weight $\%$ & $0.066 \%$ & $85.692 \%$ & $9.335 \%$ & $0.050 \%$ & $4.857 \%$ & $0.125 \%$ & & $100.00 \%$ \\
\hline weight fra/g & 0.000576 & 0.755734 & 0.0826732 & 0.0004491 & 0.04337 & 0.002227 & & $1503 \mathrm{~s}$ \\
\hline iso $\mathrm{ma}$ & $6.53 \mathrm{E}-05$ & $8.53 \mathrm{E}-02$ & $9.29 \mathrm{E}-03$ & $5.02 E-05$ & $4.83 \mathrm{E}-03$ & $1.25 E-04$ & avg mas & \\
\hline 180 mass 141 & $000006 \%$ & $0 \% 06 \% 56$ & $060186 \%$ & $60 \% 006 \%$ & 6064750 & $6060 \% 1 \%$ & mass 1 & 00699698 \\
\hline 150 nasss 12 & 0.000065 & 0.092245 & 0.009301 & $0 \% 000051$ & 00004773 & 00000124 & nnass $\% 2$ & $0.106560 \% 9$ \\
\hline 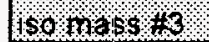 & 0.000067 & 0.07139 & 0.0096696 & 0.0000050 & $06064497 \%$ & 00000132 & 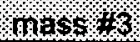 & $0.092310 \% 0$ \\
\hline
\end{tabular}

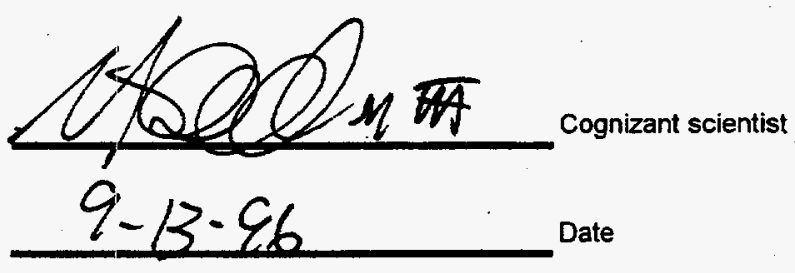


Battelle Pacific Northwest National Laboratory

Analytical Chemistry Laboratory

96-5179

RadiochemistryGroup - 325 Bldg.

$7 / 12 / 96$

\section{Client: J Vienna}

Wp \#: K42929

Cognizant Scientist:

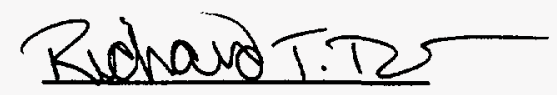

Date :

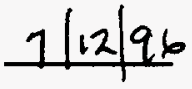

Concur :

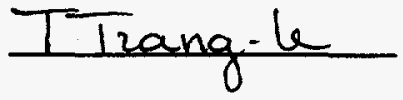

Date : $\quad 7 / 12 / 96$

Measured Activities (uCi/g)

ALO ID

Client ID

96-5179Pb

Vienna 1 process Blank

96-5179

Vienna 1

Total Alpha

Error \%

$8.66 \mathrm{E}-3$

$21 \%$

$7.47 \mathrm{E} 3$

$6 \%$

96-5180

$7.45 \mathrm{E} 3$

Vienna 2

$6 \%$

96-5181

$7.26 \mathrm{E} 3$

Vienna 3

$6 \%$

96-5182

$6.15 \mathrm{E} 3$

Vienna 4

$6 \%$

96-5183

7.21E 3

Vienna 5

$6 \%$

96-5183Dup

7.34E 3

Vienna 5

$6 \%$

Standard

$115 \%$

Blank

<2. E-3 
Battelle Pacific Northwest National Laboratory

Analytical Chemistry Laboratory

Radiochemistry Group - 325 Bldg.

Client: J. Vienna

WP \#: K45606

Cognizant Scientist:

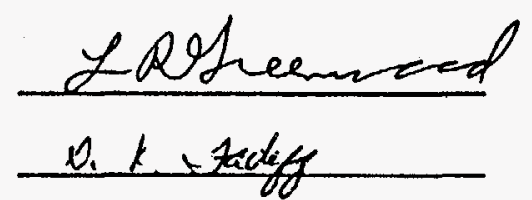

Date: $\quad \frac{8-13-96}{3 / 13 / 96}$

Thermal lonization Mass Spectrometry

Mass \%

$\stackrel{p}{t}$

\begin{tabular}{|c|c|c|c|c|c|c|}
\hline $\begin{array}{l}\text { ALO ID } \\
\text { Client ID } \\
\end{array}$ & & Pu-238 & Pu-239 & Pu-240 & Pu-241 & $\mathrm{Pu}-242$ \\
\hline $\begin{array}{l}96-5179 \\
\text { Vienna-1 }\end{array}$ & & 0.012 & 93.340 & 6.411 & 0.194 & 0.043 \\
\hline $\begin{array}{l}96-5180 \\
\text { Vienna-2 }\end{array}$ & & 0.011 & 93.349 & 6.415 & 0.189 & 0.036 \\
\hline $\begin{array}{l}96-5181 \\
\text { Vienna-3 }\end{array}$ & & 0.015 & 93.362 & 6.387 & 0.197 & 0.039 \\
\hline $\begin{array}{l}96-5182 \\
\text { Vienna-4 }\end{array}$ & & 0.013 & 93.383 & 6.375 & 0.193 & 0.036 \\
\hline $\begin{array}{l}96-5183 \\
\text { Vienna-5 }\end{array}$ & . & 0.014 & 93.338 & 6.415 & 0.190 & 0.042 \\
\hline $\begin{array}{l}\text { Standard -Measured } \\
\text { NBS SRM } 946 \text { Values }\end{array}$ & $\ldots$ & $\begin{array}{l}0.215 \\
0.210\end{array}$ & $\begin{array}{l}85.536 \\
85.567\end{array}$ & $\begin{array}{l}12.420 \\
12.400\end{array}$ & $\begin{array}{l}1.249 \\
1.242\end{array}$ & $\begin{array}{l}0.580 \\
0.582\end{array}$ \\
\hline
\end{tabular}




Calclulation sheet for weight\%
$\mathrm{t} 1 / 2$

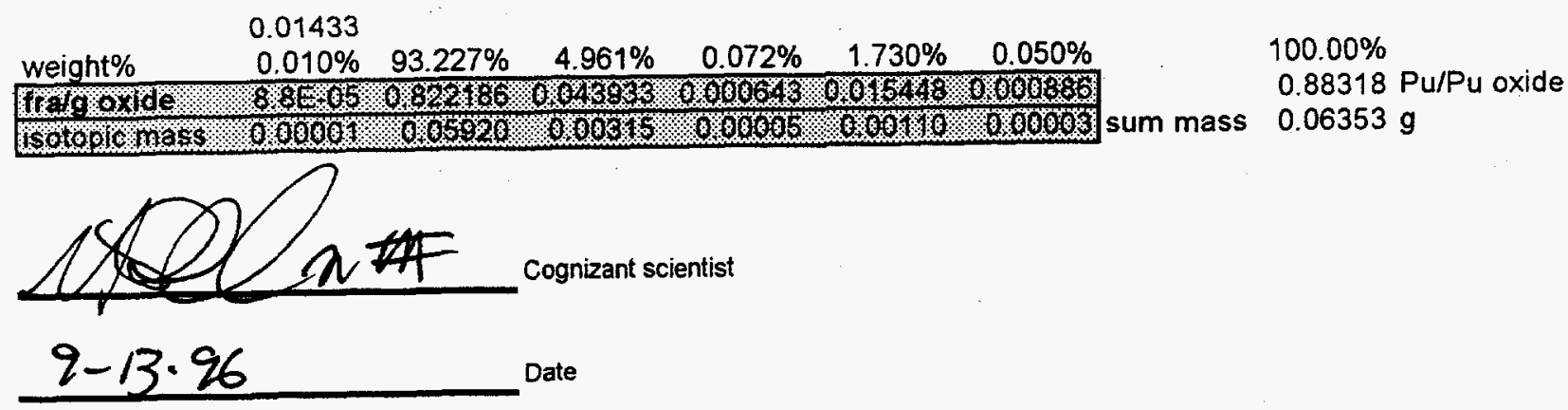


Calclulation sheet for weight $\%$

$\mathrm{t} 1 / 2$

sample: 87.7

$\mathrm{PuO} 2 \mathrm{~mol}$

271 grams

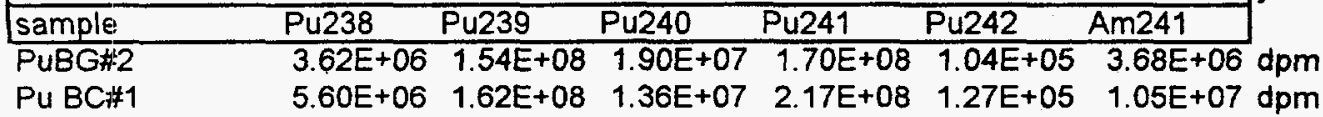

$\mathrm{Pu}$ BC搔2 $\begin{array}{llllll}4.40 E+06 & 1.53 E+08 & 1.91 E+07 & 1.94 E+08 & 1.01 E+05 & 6.53 E+06 \\ d p m\end{array}$

weight \%

$0.010 \% \quad 96.012 \% \quad 2.859 \%$

$0.061 \%$

$1.059 \%$

$0.076 \%$

8.76E-05 8.47E-01 2.53E-0

$25.42 \mathrm{E}-04$

$\begin{array}{lll}5.92 \mathrm{E}-06 & 5.70 \mathrm{E}-02 & 1.70 \mathrm{E}-03\end{array}$

$3 \quad 3.62 \mathrm{E}-05$

$9.46 E-03$
$6.28 E-04$

$1.35 \mathrm{E}-03$

Sum

$0.00 \%$

0.88349

iso mass avg

2. 1.67 .003

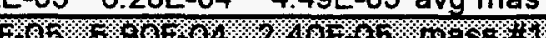

0.0594

......

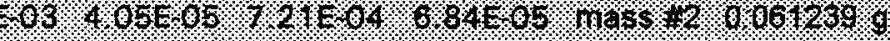

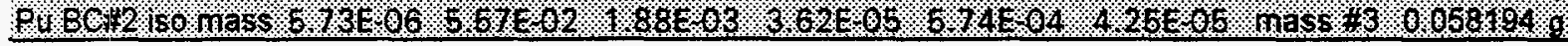

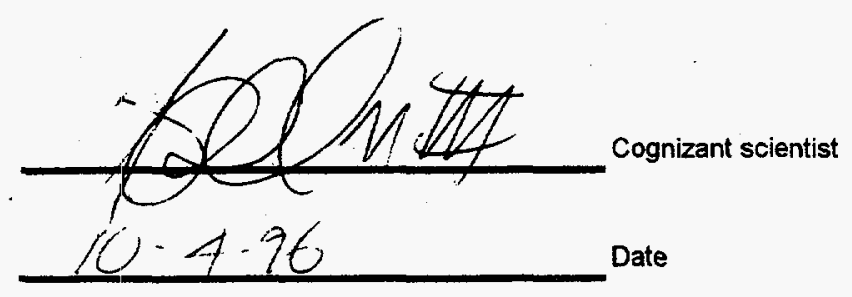

